\title{
Die rol van "historisiteit" in die kommunikasie van die wondervertelling. 'n Evaluering van twee eksegetiese benaderinge
}

\author{
EJ VLEDDER
}

\section{PROBLEEMSTELling}

"Literatuur is ... primêr daarop ingestel om iets te kommunikeer en dit is trouens ' $n$ voorwaarde vir literatuur dat dit moet kommunikeer" (Vorster 1977: 18). Wat vir literatuur geld, geld ook vir die "wondervertellinge", wat as 'n klein deeltjie van die breëre begrip "literatuur" beskou kan word. Die "wondervertellinge", soos enige ander Bybelse literatuur, moet vir die mens van die twintigste eeu kommunikeerbaar gemaak word. Hieronder word verstaan dat die "wondervertellinge" in vandag se situasie moet inspreek. Dit kan alleen gebeur as die skrywer en die leser dieselfde verwysingsraamwerk het. Hier lê egter die probleem. Die verwysingsraamwerk van die wonder en die hedendaagse mens is nie dieselfde nie, omdat twintig eeue hulle skei. Hierdie verwysingsraamwerk wat verskil, bewerk 'n kloof tussen die wonderverteller en die twintigste-eeuse leser. Dié kloof belemmer op sy beurt kommunikasie. Om kommunikasie te laat plaasvind, moet hierdie kloof oorbrug word, en dit moet gedoen word aan die hand van 'n bepaalde metode van interpretasie. Die vraag is egter watter benaderingswyse gevolg moet word. Watter benaderingswyse kan kommunikasie teweegbring? Is daar 'n benaderingswyse wat ' $n$ "vertelling" beter as ander benaderingswyses kan laat kommunikeer? Of is dit selfs moontlik dat 'n bepaalde benaderingswyse die moontlikheid van kommunikasie geheel en al kan afsny en onmoontlik maak? Ten opsigte van die moontlikheid dat 'n bepaalde benaderingswyse kommunikasie kan afsny, stel Vorster (1977: 11) die volgende: "Binne die raamwerk van 
die historiese kritiek ... kan die Nuwe testament nie as antieke geskrif, soos dit daar staan, in die moderne wêreld kommunikeer nie ..."

Die vraag waarom dit dus gaan, is watter benaderingswyse of metode van interpretasie aangewend moet word, om die "wondervertelling" ten beste verstaanbaar en kommunikeerbaar te maak. Dit is veral ten opsigte van die aspek "kommunikasie" dat die "wondervertelling" myns insiens nie binne die raamwerk van die historiese kritiek kommunikeerbaar is nie en dat hierdie benaderingswyse daarom in hierdie opsig ontoereikend is. Die rede hiervoor is myns insiens geleë in die feit dat "historisiteit" as doel op sigself in die histories-kritiese metode van uitleg funksioneer, terwyl die rekonstruering van "historiese feite" (dit wil sê, die beskrywing van "wie es eigentlich gewesen ist"), nie 'n voorwaarde van kommunikasie van die "wondervertelling" hoef te wees nie.

Om dié tese te beredeneer, is die volgende in die ondersoek van belang: eerstens word daar by wyse van ' $n$ begripsoriëntering (afdeling 2) aangetoon wat onder "kommunikasie as hermeneutiese onderneming" (afdeling 2.1), "wondervertelling" (afdeling 2.2), en "historisiteit en Eksegese en Teologie" (afdeling 2.3), verstaan word. Tweedens word die historiese kritiek as hermeneutiese model (afdeling 3) bespreek. Daar sal na 'n kort bespreking van die historiese kritiek (afdeling 3.1) aangetoon word dat die historiese kritiek kommunikasie belemmer (afdeling 3.2) en dat nòg Rudolf Bultmann (afdeling 3.3), nòg Peter Stulmacher (afdeling 3.4), wat altwee eksponente van die historiese kritiek is en wat wel die leemtes daarvan probeer oorbrug het, daarin slaag om 'n tekstipe soos 'n "wondervertelling" te laat kommunikeer. In afdeling 3.5 word hierdie ontoereikendheid aan die hand van 'n histories-kritiese uitleg van Johannes 4:43-54 geïllustreer. Derdens word ' $n$ alternatief op die historiese kritiek gebied waardeur 'n "vertelteks", soos 'n "wondervertelling", kommunikeerbaar gemaak kan word (afdeling 4). 'n Narratiewe studie laat meer reg geskied aan die hermeneutiek van die "wondervertelling" (afdeling 4.1), omdat daar 'n onderskeid gemaak word tussen 'n "vertelde wêreld" en die "werklike wêreld" (afdeling 4.2) en omdat die begrippe "historisiteit" en "kommunikasie" in ' $n$ narratiewe uitleg anders hanteer word as in die historiese kritiek (afdeling 4.3). Dit word aan die hand van 'n narratiewe uitleg van Markus 2:1-12 geillustreer (afdeling 4.4). Die resultate van die ondersoek word dan ten slotte (afdeling 5) kortliks saamgevat. 


\section{BEGRIPSORIËNTERING}

\subsection{Kommunikasie as hermeneutiese onderneming}

\subsubsection{Hermeneutiek}

Dit is nie die bedoeling om hier in diepte op die filosofiese, linguïstiese of teologiese hermeneutiek in te gaan nie. Enkele aspekte moet egter aangesny word. Hermeneutiek is die wetenskap van verstaan, of soos Frör (1964: 12) dit stel: 'n mens kan hermeneutiek "... einmal ganz allgemein als Lehre vom Verstehen bezeichen ..." Dit is egter nog baie breed gestel. In die hermeneutiek gaan dit om dié wesenlike vraag, soos Barr (1973: 42) dit stel: "What is the right way of interpreting the Bible for today?" (Kursifering deur myself). Thiselton (1979: 310) haal Fuchs aan, wat 'n soortgelyke vraag stel: "How do I come to understand?"

Om tot die verstaan van 'n teks te kom, moet daar 'n bepaalde werkwyse gevolg word: "The principles of Biblical hermeneutics are those governing laws and methods of procedure by which the interpreter determines the meaning of the Holy Scriptures" (Terry 1976: 161; kursifering deur myself). Die werkwyse wat gevolg word om by die verstaan van die teks uit te kom, hang ten nouste saam met die benaderingswyse of eksegetiese metode van die interpreteerder. Onder hermeneutiek word hier dus bedoel die benaderingswyse wat gevolg word om 'n teks te interpreteer en te verstaan.

Die metode van uitleg, oftewel die benaderingswyse, hang baie af van die vooronderstelling waarmee die interpreteerder na die teks gaan. Verder is dit algemeen bekend dat vooronderstellinglose uitleg nie moontlik is nie. "It is possible to minimise the influence of presuppositons; it is not possible to begin to interpret a text without approaching it from a particular angle .... The attempt to interpret the New Testament from a neutral detached standpoint ... has largely been abandoned" (Standton 1979: 66). Tog mag daar nie aan enige vooronderstelling, en so ook nie aan enige uitlegmetode of benaderingswyse vrye teuels gegee word nie. Hierdie vooronderstelling moet geverifieer kan word en self ook bevraagteken kan word. Standton (1979: 69) meen tereg dat die vooronderstelling (en ook enige benaderingswyse), altyd in die tweede plek staan: “... they must be no more than a door through which the text is approached. The text is prior: the interpretor stands before it humbly and prays that through the scholarly methods and questions with 
which he comes to the text, God's Word will be heard afresh." Die interpreteerder tree met vooronderstelling en al in dialoog met die teks. Dit hang saam met wat in die hermeneutiek as die "hermeneutiese sirkel" bekend staan. Die interpreteerder gaan met sy vooronderstelling èn benaderingswyse na die teks, maar die teks behoort hom dan daarna aan te spreek. So kan sy eie vooronderstellings gekritiseer, getemper, verbreed-of gewysig word. Frör (1964: 55) stel dit soos volg: "Und das genaue Hinhören auf das, was der Text faktisch sagt, wirkt auf das Vorverständnis zurüch", of soos Hasel (1978: 58) dit formuleer: "Man is to be interpreted or addressed through the medium of the text." Vooronderstellings en benaderingswyses moet dus voortdurend aan die teks getoets word.

'n Verdere probleem is die feit dat hoeveel interpreteerders met die Bybel omgaan, soveel verskillende interpretasies is daar. Verder het die verskillende metodes van eksegese respektiewelik verskillende resultate teweeggebring. Selfs dieselfde benaderingswyse het verskillende resultate opgelewer. Daarom stel Lategan (1982: 83) dit tereg: "Juist wegens de complexiteit (van die teks - EJV) is het mogenlijk om een gevarieerd aantal vragen aan de tekst te stellen en deze op meer dan een vlakken te onderzoeken." Die probleem bly egter dat, as die aard van die resultaat van Bybeleksegese so baie van die metode van interpretasie afhang, wie besluit dan watter metode van interpretasie gebruik moet word (kyk Barr 1973: 96)? 'n Antwoord op hierdie vraag is nie maklik nie, maar dit lyk tog of daar, in aansluiting met die vorige paragraaf, na die teks self teruggegaan moet word om te bepaal watter metode(-s) van interpretasie legitiem of illegitiem is.

Dit moet baie duidelik gestel word dat die vasstelling van die betekenis van 'n teks wat as resultaat van 'n bepaalde metode van interpretasie bereik is, nooit verabsoluteer mag word nie: “... you have no right ever to say that any of this wide range of possibilities (van betekenisse - EJV) is the meaning" (Barr 1973: 72; kursifering deur Barr self). Dit geld ook vir die verskillende benaderingswyses in die hermeneutiek; daar bestaan nie so iets soos 'n absolute "die" metode van interpretasie nie.

\subsubsection{Kommunikasie}

Wat word onder die begrip "kommunikasie" verstaan? Anderegg (1973: 11) beskou kommunikasie as ' $n$ interpersoonlike gebeurtenis 
waartydens ' $n$ bepaalde mededeling oorgedra word. Hy gee die volgende aanvaarbare definisie:

"Kommunikation ... heisst jene durch Sprache aktualisierte Beziehung zwischen einem Sender und einem Empfänger, die mit der Intention des Senders übereinstimmt, die also dadurch characterisiert ist, dass die beim Empfänger durch die Mitteilung ausgelöste Wirkung der Absicht des Senders entspricht" (Anderegg 1973: 17).

Dit is dus van die begin af duidelik dat daar ten minste twee partye by kommunikasie betrokke moet wees, naamlik 'n sender en 'n ontvanger. Petersen (1978a: 35) se gebruikmaking van Roman Jakobson se kommunikasiemodel kan in hierdie verband as verdere uitbreiding by die definisie van Anderegg dien:

"The ADDRESSER sends a MESSAGE to the ADDRESSEE. To be operative the message requires a CONTEXT referred to ("referent" in another, somewhat ambiguous nomenclature), seizable by the addressee, and either verbal or capable of being verbalised; a CODE fully, or at least partially common to the addresser and addressee (or in other words, to the encoder and decoder of the message); and, finally, a CONTACT, physical channel and psychological connection between the addresser and addressee, enabling both of them to enter and stay in communication."

Opsommend kan dit so gestel word: Die sender kodeer sy boodskap in ' $n$ bepaalde kode wat deur die ontvanger gedekodeer word (Lategan 1982: 51). Hierdie model kan soos volg geskematiseer word:

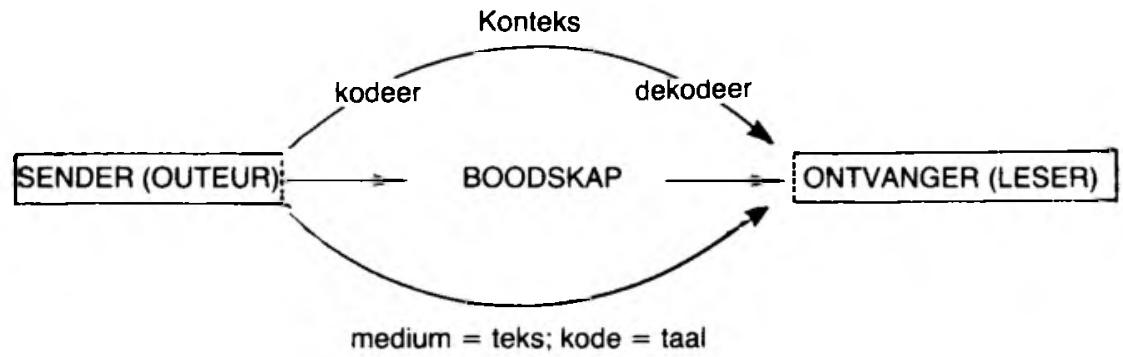


Kommunikasie is pas geslaagd wanneer die sender daarin slaag om sy boodskap by die ontvanger tuis te bring, maar ook wanneer die ontvanger die boodskap van die sender kan aanneem, verwerk, verstaan en sy eie maak. Dit impliseer dat die konteks as die lewensverband van die boodskap, sowel as die kode vir beide die sender en ontvanger verstaanbaar is. Dit impliseer dus sowel ' $n$ bepaalde verwysingsraamwerk as ' $n$ toereikende taalkennis by beide die sender en die ontvanger (Vorster 1977: 20).

Wanneer die boodskap van die sender 'n geskrewe teks of literatuur as medium het, kom daar volgens Vorster (1977: 18) 'n belangrike aspek by wat kommunikasie moontlik maak. Dit is naamlik dat kommunikasie van 'n boodskap ooreenkomstig die tekssoort waarin dit gegiet is, plaasvind. Daarom moet die tekssoort in ag geneem word, alvorens die teks werklik kan kommunikeer. Vorster (1977: 18), in aansluiting by Anderegg, onderskei in die Nuwe Testament tussen twee tekssoorte, naamlik "saak-" en "fiktiewe" tekste. Elkeen van hierdie twee tekssoorte het elk sy eie voorwaardes van kommunikasie.

Opsommend is die voorwaardes vir kommunikasie van "saaktekste" soos volg:

1. die leser en die ontvanger moet dieselfde verwysingsraamwerk hê;

2. die leser moet dieselfde betekeniservaring van die skrywer se taalgebruik hê;

3. die saak moet vir die leser relevant wees sodat sy verwysingsraamwerk verbreed kan word;

4. kommunikasie moet vir die leser aktueel wees.

Kommunikasie vind by "fiktiewe tekste" anders plaas. Vorster (1977: 19) stel dit soos volg: "Fiktiewe tekste is nie tekste wat uit die duim gesuig is nie, of wat nie waar is nie, maar dit is tekste waarin die werklikheid binne die teks self geskep word sonder dat daar in dié tekste, soos in saaktekste, in 'n een tot een verhouding na persone of aangeleenthede buite die teks verwys word." Myns insiens is die voorwaarde vir kommunikasie van "fiktiewe tekste" en daarom ook die "wondervertelling", inderdaad anders as dié van "saaktekste" en wel dat daar gevra sal word na die boodskap van die sender. Die leser en die sender hoef nie vooraf dieselfde verwysingsraamwerk te hê nie. Die verwysingsraamwerk word deur die teks self daargestel. Die sender en die ontvanger is fiktief, in die sin 
dat die leser (wat enige persoon kan wees), as 't ware inval by die fiktiewe ontvanger, en hy “... laat sy verwysingsraamwerk bevra deur dié van die fiktiewe sender" (Vorster 1977: 20). Kommunikasie vind by "fiktiewe tekste" dus plaas tussen die fiktiewe sender ("geïmpliseerde outeur") en die leser as fiktiewe ontvanger ("geïmpliseerde leser"), "... wat oor die nodige betekeniservaring beskik en bereid is om hom onophoudelik te laat bevra deur die saak wat in die teks aan die orde is" (Vorster 1977: 20).

Dit bly dus belangrik dat die "wondervertelling" as "fiktiewe teks", geïnterpreteer moet word ter wille van geslaagde kommunikasie (vergelyk afdeling 2.2.3).

\subsection{Die "Wondervertelling"}

Reeds in 1961 het Kallas (1961: 1) die volgende gestel: "There is a paradoxical fact relative to the miracle in modern theology today. On the one hand, the miracles furnish us with the greatest portion of the gospel narratives. ... The other side of the paradox is this: that despite of the gospel narrator's insistence upon the centrality of the miracles, modern theology has almost completely ignored the subject." Myns insiens het die posisie vandag nie verbeter nie. Behalwe dat die wonders 'n baie omstrede onderwerp is, waaroor weinig werklik die vrymoedigheid het om 'n mening te waag, is die rede myns insiens waarom die wonders nie baie in die eksegese aandag kry nie, geleë in die feit dat daar nie sekerheid bestaan oor watter benaderingswyse of metode van interpretasie, relevant is by die uitleg van die "wondervertellings" nie.

Daar is tot op hede weinig oor die wonders as sodanig gepubliseer. Wanneer daar wel oor Jesus se wonders geskryf word, word daar meestal baie sterk klem gelê op die feit dat Jesus wonders gedoen het om die mag van die Satan en die duisternis te verbreek en om die koms van die Koninkryk van God aan te kondig. Die heerskappy van Satan is beëindig en die wonders is bewys daarvan. Dit is dan ook die teleurstellende van iemand soos Kallas (1961) se werk. Hy het, desnieteenstaande die hierbo aangehaalde opmerking, ook daarin verval om dié wonders slegs as bewys van God se heerskappy te sien: "Thus the coming of the kingdom of God finds its verification in the driving out of demons and the healing of disease" (Kallas 1961: 80) en: "Thus the miracles of healing and exorcism are signs that the kingdom is coming ..." (Kallas 1961: 83). 
Vir Kallas (1961: 88) is die natuurwonders die duidelikste bewys van die heerskappy van God (vergelyk ook Fuller 1963). Dit op sigself is nie verkeerd nie, maar die probleem in die aanwending van die wonders as bewyse, is dat die wyse van benadering baie breed is en dat dit hoogstens ' $n$ hermeneutiese sleutel bied tot die uitleg van die wonders as 'n groep magsdade, terwyl dit nie veel bydra tot nòg die uitleg van 'n individuele wonder op sigself, nòg die uitleg van 'n "wondervertelling" as tekstipe nie".

Of die wonders as sodanig wel moontlik of verklaarbaar is, word daar hier nie op ingegaan nie. Dat wonders verklaar kan word as belewenisse deur die primitiewe mens van bepaalde natuurverskynsels, wat nie inpas in die hedendaagse lewe nie, omdat alles in die natuur empiries bewysbaar moet wees (vergelyk Van der Loos 1968), is hier nie ter sake nie. 'n Saak wat in die verlede wel baie aandag geniet het, is die vraag of dit Jesus self (met ander woorde die sogenaamde "historiese Jesus") was wat die wonders gedoen het en of dit weergawes van die vroeg-Christelike tradisies aangaande wonderdade is, wat nie noodwendig op die "historiese Jesus" terug hoef te gaan nie. Petzke (1976: 180) stel dit so: "Trotz einer jahrhundertelange ausgiebigen Diskussion ist offensichtlich bis heute noch keine Einigung darüber erzielt worden, ob der historische Jesus selbst Wunder vollbracht hat oder ob es sich bei den Wundertraditionen des Neuen Testamentes um eine nachträgliche Titulierung Jesu als eines Wundertäters durch die Gemeinde handelt." Hierdie probleem hang saam met die sogenaamde probleem van "historisiteit" wat baie maklik verabsoluteer kan word, soos dit inderdaad ook binne die historiese kritiek gebeur het (vergelyk afdeling 3.1) en dit kan op sy beurt die kommunikasie van die "wondervertellinge" benadeel (vergelyk afdeling 3.2).

Hoewel dit in die onderhawige ondersoek hoofsaaklik gaan om die "wondervertellinge", staan laasgenoemde nie los van die begrippe "wonders" en "wonderdade" nie.

\subsubsection{Wonders}

In die populêre spreektaal word die begrip "wonder" baie wyd verstaan. Iets word baie maklik as 'n "wonder" beskou as dit afwyk van die normale verwagting. Iets is dan 'n "wonder" as dit wat gebeur het, teen die verwagting in ten goede van die mens strek. Tog vind dit, alhoewel teen die mens se verwagting, wel in die alledaagse lewe plaas en is dit in der waarheid nie bonatuurlik van 
aard nie. Die oorsake van dit wat as "wonder" beskou was, kan met ander woorde na deeglike ondersoek, bepaal en verklaar word.

In aansluiting met wat hierbo gesê is, moet daar nou enkele beskrywings gegee word van wat dan wel as "wonder" beskou kan word. Thomas (aangehaal deur Van der Loos 1965: 35) stel dit soos volg: "A Miracle is ... that which, so to speak, is wondered at by all." Swinburne (1970: 1) beskou ' $n$ "wonder" as "... an event of extraordinary kind, brought about by a god, and of religious significance." Fuller (1963: 8) is van mening dat 'n "wonder" 'n gebeurtenis is wat teenoor die bekende in die natuur staan. Woods (1965: 22) sien wonders as werke "... beyond the power of man and recognisable as the works of God." Van der Loos (1965: 46) gee die volgende definisie van 'n wonder:

(a) 'n wonder is 'n vorm van goddelike openbaring;

(b) 'n wonder kan alleen in die geloof werklik verstaan word;

(c) ons kan alleen van 'n wonder praat as dit 'n gebeurtenis is wat buite en teen die bekende orde in die natuur plaasvind;

(d) elke wonder het betekenis, in die sin van redding of straf vir die persoon wat daarby betrokke is, maar ook vir die hele mensdom;

(e) in wonders manifesteer God se vryheid, krag en liefde.

Opsommend kan die volgende definisie van 'n "wonder" gegee word: 'n Wonder is 'n gebeurtenis waarvan die oorsaak obskuur en onverklaarbaar is en wat buitengewoon en bonatuurlik van aard is. Dit vind plaas buite die mens om en kan as die werk van God beskou word. ' $n$ Wonder vind sy godsdienstige betekenis daarin dat dit in die geloof aanvaar moet word.

'n Wonder kan verskillende gestaltes aanneem. Fuller (1963: 37) beweer tereg dat die Nuwe-Testamentiese skrywers nie doelbewus die wonders in klasse verdeel het nie: "No New Testament writer would have thought of putting the 'nature miracles' in a separate class." Dit geld ook vir die ander soorte wonders. Tog moet die wonders om sistematiese en akademiese oorwegings onderskei word. Fuller (1963) onderskei drie soorte wonders, naamlik natuurwonders, genesingswonders en eksorsismes. "Natuurwonders" word dan volgens hom baie breed beskou. Betz (1977: 82-3) onderverdeel nog fyner deur ook "teofanieë" (Godsverskynings) van die res te onderskei. So beskou hy Markus 4:35-41 ("Jesus maak die storm stil") en Markus 6:45-52 ("Jesus loop op die see"), as "teofa- 
nieë". Hierdie onderskeid is myns insiens onnodig, omdat teofanieë meer tuishoort in die Ou Testament en omdat hierdie spesifieke wonders baie maklik as natuurwonders beskou kan word wat iets van Jesus se mag oor die natuur aantoon. Pesch (1970: 12) onderskei óók 'n vierde soort "wonder", naamlik die sogenaamde "opwekkings" (byvoorbeeld Johannes 9:1-7 waar Lasarus uit die dood opgewek word of Lukas 5:1-11 waar Jesus die seun van die weduwee opwek). Maar ook dit is myns insiens 'n onnodige onderskeiding, omdat die opwekkings as 'n geïntensifeerde genesingswonder beskou kan word. Fuller (1963) se onderskeiding word gehandhaaf en die volgende kan kortliks onder elkeen verstaan word:

(a) Natuurwonders: Dit is wonders wat teen die natuur se wetmatighede in plaasvind, as gevolg van 'n mag wat hoër en magtiger is as hierdie wetmatighede.

(b) Genesingswonders: Wonders wat plaasvind teen alle mediese wetmatighede in en wat tot herstel van siekte lei.

(c) Eksorsismes: Dit is die uitdrywing van geeste wat negatief op die aangetaste persoon inwerk. Dit kan uit 'n moderne oogpunt beskou word as genesing van een of ander geestesafwyking.

\subsubsection{Wonderdade}

Hieroor kan kortliks gehandel word omdat die onderskeid tussen 'n "wonder" as gebeurtenis en 'n "wonderdaad" 'n kwessie van beklemtoning is. ' $n$ Wonderdaad is daardie daad wat deur 'n bo-menslike of bo-natuurlike en outentieke agent bewerkstellig word. 'n Wonderdaad word bepaal deur die agent wat dit bewerkstellig. Dit is daardie "werklikheid" wat plaasvind deur die toedoen van die agent en wat in die geloof aanvaar moet word. Vir doeleindes van hierdie studie gaan dit om die wonderdade van Jesus, met ander woorde, daardie dade wat deur die toedoen van Jesus as goddelike wese (oftewel God self) plaasvind.

\subsection{3 "Wondervertelling"}

Voordat daar oor die "wondervertelling" gehandel word, moet daar eers kortliks 'n definisie van die begrip "vertelling" gegee word: "'n Vertelling is ' $n$ diskoers waarin taal georganiseer is in terme van karakters wat in 'n bepaalde struktuur van tyd en ruimte beweeg en 'n 
kronologiese sekwensie van episodes meebring wat in kousale verband tot mekaar staan (Plot ..." (Van Aarde [1983a]; kursifering deur Van Aarde self). Die wondervertelling word tereg deur Funk (1978: 57) as 'n "mini-narrative" beskou, omdat 'n wondervertelling wel aan die eise van 'n vertelling voldoen. 'n "Wondervertelling" is daardie vertelling waarin die verteller van 'n bepaalde wonderdaad van Jesus as hoofkarakter vertel, meestal binne 'n breëre raamwerk. 'n "Wondervertelling" skakel in by die breëre raamwerk van 'n evangelie: "The miracle-stories have indeed a very strong place in the gospel tradition" (Glasswell 1965: 152). Anders gestel: 'n "wondervertelling" as tekstipe, val in by die evangelie as tekssoort (vergelyk voetnoot 1$)$.

Van der Loos (1965: 120-130) gee 'n aantal tipiese eienskappe wat hy as eie aan die "wondervertelling" beskou en wat meestal in die onderstaande volgorde plaasvind:

(a) Die aard, erns en tydsduur van 'n kwaal word beskryf.

(b) Daar is ' $n$ mislukking van bekende medisyne (of middele).

(c) Die wonderbewerker word meestal bespot (of deur sy teenstanders met argwaan bejeën).

(d) Daar is ' $n$ moeilikheidsgraad aan die genesing (of ander wonders) verbonde.

(e) Daar is onenigheid tussen die wonderbewerker en die pasiënt (en soms ook met die omstanders).

(f) Die behandeling van die siekte.

(g) Die bewys van die werklike genesing (of oplossing van die probleem).

(h) Die genesing (of oplossing) vind gewoonlik onmiddellik met die uitspreek van die "genesingswoorde" plaas.

(i) Dan volg daar die smeking, verdediging en reaksie op die demone.

(j) Die omstanders (dit wil sê die dissipels, Joodse leiers en volk) reageer.

Uit die oogpunt van die rasionalisme is dit 'n vraag of die "wondervertelling" outentiek is, met ander woorde of die wonderdade van Jesus wel werklik so plaasgevind het soos wat dit vertel is. Die probleem is dat " ... while the traditions that Jesus did perform exorcisms and healings is very strong, we can never be certain of the authenticity of any actual miracle-story in the gospels" (Fuller 1963: 39). Hiermee word die problematiek van die "historisiteit" van die 
wondervertellinge aangeraak en die relevansie van "historisiteit" veral met betrekking tot die eksegese en kommunikasie daarvan (vergelyk afdeling 2.3 hieronder).

\section{3 "Historisiteit" in Eksegese en Teologie}

Die begrip "historisiteit" word meestal aangewend wanneer daar verwys word na gebeure in die verlede wat as feitelik korrek met behulp van òf kontemporêre bronne bewys kan word òf wat uit mondelinge weergawes van ooggetuies bevestig kan word ò wat na aanleiding van die skema "oorsaak en gevolg" verklaar kan word. Die begrip "historisiteit" word dikwels met die begrip "feitelikheid" gelykgestel, dit wil sê die "bruta facta" van 'n gebeurtenis. Dit word dan aangewend om te verwys na 'n gebeurtenis wat werklik op 'n bepaald punt in die geskiedenis en in die verlede plaasgevind het. Die taak van die historikus is om hierdie feite so presies en korrek, sowel as so verifieerbaar moontlik weer te gee. Harvey (1967: 4) beweer tereg dat die doel van die historikus is om te vertel "wat presie gebeur het". Die tower selfstandige naamwoord is "feite" en die geëerde byvoeglike naamwoord is "wetenskaplik" (vergelyk afdeling 3.1). Die term "historisiteit" word dus gebruik in samehang met die terme "feitelikheid" en "werklike weergawe" van 'n berig. Dit kan byvoorbeeld gesê word dat die "historisiteit" van die bomontploffing in Kerkstraat in Pretoria op 20 Mei 1983, bo alle twyfel vasstaan en feitlik in ' $n$ berig weergegee kan word, omdat hierdie gebeurtenis deur verskillende dagblaaie, maar ook aan die hand van lewende ooggetuies bevestig kan word. Maar wanneer gebeurtenisse verder in die verlede plaasgevind het, raak die vasstelling van "historisiteit" moeiliker, veral as die bronne beperk is en die ooggetuies reeds oorlede is.

Daar bestaan ook verdere probleme ten opsigte van historiese beskrywings van gebeurtenisse in die verlede. North (1962: 607) beweer dat daar vir die historikus nie so iets is soos "naakte feite" nie, omdat twee waarnemers, selfs van 'n enkele kontemporêre gebeurtenis, “. . can nearly always be relied upon to report it in ways that not only differ, but may, in part at least, appear to contradict one another." Dit is so omdat feite altyd geinterpreteer word volgens die invalshoek van die waarnemer en ook dié van die historikus. Die historikus gebruik dikwels feite bloot as verduidelikings; soms doen hy dit suiwer deskriptief of ter wille van evaluasie of ter wille van 'n 
bepaalde etiek ("moral") (Abrahams 1982: 117). 'n Historikus oordeel meestal vanuit sy eie vooronderstellinge en dikwels word die verlede in die lig van die hede beoordeel (Abrahams 1982: 119). Dit alles dra daartoe by dat historiese gegewens met groot versigtigheid en oordeelkundigheid beoordeel sal moet word, alvorens dit as feitelik korrek of as histories betroubaar aanvaar sal word, veral as die gebeurtenisse baie ver in die verlede lê; selfs al bevestig 'n hele aantal bronne dit en al kan dit in terme van oorsaak en gevolg verklaar word.

Tot dusver is daar nog net baie breedweg oor "historisiteit" ten opsigte van sekulêre gebeure gehandel. Ten opsigte van die Bybelse gegewens raak die probleem van historiese betroubaarheid moeiliker omdat baie van die gebeurtenisse nie altyd met die rede ò in terme van oorsaak en gevolg ò by wyse van bevestiging deur ander bronne ò met behulp van ooggetuies, as waar bewys kan word nie. Dit is veral moeilik om die "historisiteit" van byvoorbeeld die wonderdade van Jesus of die opstanding van Jesus te bepaal, omdat dit sake is wat moeilik peilbaar is vir die menslike rede en omdat dit deur feitlik geen ander bron as die Bybel bevestig word nie. Daarom word hierdie sogenaamde "openbaringsgebeure"2 dikwels betwyfel en as onhistories en onwerklik afgemaak, veral wanneer dit uitgelewer word aan die sekulêre beginsels van "historisiteit" en rasionalisme. Om een voorbeeld te noem van hoe daar probeer is om uit die probleem te kom dat die Bybelse gebeure nie rasioneel verklaar en histories bewys kan word nie, kan na Strauss (1808-1874) verwys word (kyk Van der Loots 1968). Strauss het die lewe en optrede van Jesus grootliks as "mites" verklaar ${ }^{3}$. "Mites" is volgens hom rasioneel verklaarbaar en is as sodanig histories bepaalbare gegewenhede. So het Strauss ook die wonders as "mites" verklaar. Strauss formuleer dit soos volg: "An account is not historical when it proves: (a) that it is irreconcilable with the known and moreover universally applicable laws of events (causality, succession, psychological laws); (b) that the account contains internal contradictions or one account is in conflict with another (these contradictions may relate to form and material). Nor is an account historical if it can be positively recognized as a myth ..." (aangehaal deur Van der Loos 1968: 20).

Om nie-rasionele sake sonder meer as mites te beskou soos wat Strauss doen, is myns insiens baie eensydig omdat dit nie rekening hou met die geweldige impak wat ' $n$ "mite", soos byvoorbeeld die opstanding van Jesus op die vroeë kerk en ook op die hedendaagse 
kerk het nie. Met die opmerking van Strauss hierbo word geillustreer wat gebeur as die "openbaringsgebeure" oorgelewer word aan die rasionalisme en die sekulêre beginsels van "historisiteit", naamlik dat dit as mites en derhalwe as onwerklik afgemaak en gerelativeer word (vergelyk afdeling 3.3.1).

Wat die probleem ten opsigte van die term "historisiteit" in die teologie bemoeilik, is dié feit dat daar nie algemene eenstemmigheid is wat die term in die teologie beteken nie. Die begrip "historisiteit" kan verskillende verwysings hê, naamlik:

(a) "Historisiteit" as "bruta facta" of "hoe dit eintlik gebeur het" ("wie es eigentlich gewesen ist"); met ander woorde, presies hoe die gebeure waarna die Bybel verwys, plaasgevind het.

(b) "Historisiteit" as begrip wat gebruik word in soverre dit die wordingsgeskiedenis van die teks raak.

(c) "Historisiteit" as begrip om die historiese agtergrond waarteen die teks hom afspeel, aan te dui.

(d) "Historisiteit" in verwysing na dit wat die na-pase gemeenskap as "histories" korrek aanvaar het op grond van mondelinge oorleweringe, sonder dat dit noodwendig die toets van die moderne historiografie sal deurstaan omdat daar 'n verskil is tussen die antieke en moderne geskiedskrywing en ook omdat sekere Bybelse geskrifte (byvoorbeeld die Evangelies) nie bedoel was om as historiese geskrifte opgeneem te word nie. In verband met die verskil tussen antieke en moderne historiografie, stel die GKN-rapport (1981: 6) tereg die vraag of dit korrek is dat die Bybel as 'n wetenskaplik-geografiese boek of as 'n natuurwetenskaplike boek beskou kan word: “... hebben wij er wel voldoende rekening mee gehouden, dat ook die manier van historiebeschrijving niet westers-wetenschappelijk was?"

Dit bring ons terug by die vraag na die verifieerbaarheid van die Bybelse gegewens. Strauss het reeds aangetoon dat die gegewens oor Jesus (en by implikasie ook die hele Bybel) nie verifieerbaar is nie, tensy dit as mite beskou word. Deur die moderne geskiedskrywing blyk die Bybelse gebeure ook nie verifieerbaar te wees nie, tensy daar rekening gehou word met die antieke geskiedsbeskrywing en dit is nie 'n maklike taak nie. Ten opsigte van die wonders (en by implikasie seker ook die res van die Bybelse gebeure), stel Van der Loos (1968: 5) dit soos volg: "Indeed, the development of physics, astronomy, chemistry and biology has provided not the 
slightest support for miracles." Dit lyk dus of the Bybelse gebeure en veral die "openbaringsgebeure", moeilik - indien enigsins - verifieerbaar is. Daarom moet daar iets bykom, naamlik 'n geloofsaanvaarding ten opsigte van die waarskynlikheid van die Bybelse gebeure en/of daar moet ' $n$ eksegetiese metode vir die uitleg en verstaan van die wondervertellinge aangewend word, waar die kommunikasie nie afhanklik van die wondervertelling se historisiteit al dan nie, gemaak word nie.

\section{DIE HISTORIESE KRITIEK AS HERMENEUTIESE MODEL}

\subsection{Grondtrekke van die histories-kritiese benaderingswyse}

Historiese ondersoek word altyd bepaal deur die gangbare filosofie van die tyd (Hasel 1978: 52). So kan die historiese kritiek met reg as 'n kind van die Aufklärung, met die rasionalisme as die gangbare filosofie van dié tyd, beskou word. Alle historiese materiaal moet met die rede verstaanbaar gemaak word voordat dit op "waarheid" aanspraak kan maak (Krentz 1975: 85).

Omdat daar in die historiese kritiek so sterk klem gelê word op die rasioneel-verklaarbare, word daar op die historiese wording van die teks gekonsentreer. Die geskiedenis van die teks (in onderskeid met die inhoud van die teks) is vir die aanhangers van die historiese kritiek in terme van oorsaak en gevolg verklaarbaar. Die Bybel word beskou as 'n boek waarin 'n hele aantal antieke geskrifte versamel is en waarvan elkeen ' $n$ eie wordingsgeskiedenis het. Die tekste self speel nie soseer 'n rol in die verstaan daarvan nie; eerder die plek en die herkoms van die teks, die invloed van die skrywer op die teks en hoe dit verstaan sou word deur die "oorspronklike" leser. Nie soseer die teks nie, maar die gedagtegang van die outeur moet nagespeur word. Verder moet die oorspronklike betekenishorisonne en verwysingsraamwerk van die teks nagevors word sodat die teks verstaan kan word. De Jonge (1982: 80) merk tereg op: “De Historisch-kritische methode benadert teksten als teksten van het verleden, functionerend binnen de kader van de geschiedenis van het vroege Christendom."

Volgens Krentz (1975: 34) moet die historiese kritiek binne die konteks van die historiese metode in die algemeen geplaas word. Die historiese kritiek probeer die vrae: "wat het presies gebeur?" en 
"waarom?", ten opsigte van die Bybelse gebeure beantwoord (Krentz 1975: 37). Die ideaal was beskrywing, onpartydigheid en objektiwiteit (Harvey 1967: 4). Krentz beweer verder dat die verskil tussen die Bybelse ondersoek en die sekulêre geskiedenis in die hoofbron, naamlik die Bybel lê en nie in die metodes wat gebruik word nie. Die ondersoekmetodes en beginsels van die sekulêre geskiedsbeskrywing is dus regstreeks op die Bybelwetenskappe met die Bybel as hoofbron, toegepas.

Alhoewel dit moeilik is om te praat van die historieskritiese metode, aangesien dit so verskillend beoefen word (Hasel 1978: 208), het Ernst Troeltsch (1865-1923) die breë beginsels van hierdie benaderingswyse soos volg beskryf: Troeltsch noem drie basisreëls vir die historiese kritiek, naamlik kritiek, analogie en korrelasie (kyk Stuhlmacher 1971: 126).

(a) Kritiek: Dit kan anders omskryf word as "metodiese twyfel" ten opsigte van die oorlewering. Dit hou in dat daar op historiese gebied slegs waarskynlikheidsoordele geld. Daar is verskeie grade van waarskynlikheid, van die hoogste tot die geringste. Elke oorlewering moet eers teen die graad van waarskynlikheid afgemeet word wat dit toekom (Troeltsch 1971: 107).

(b) Analogie: Vanuit die hedendaagse werklikheidservaring word krities beoordeel wat in die verlede moontlik of onmoontlik en werklik of onwerklik was (Stuhlmacher 1971: 127). Die middel waardeur kritiek moontlik is, is die aanwending van analogie. Die analogie van die dinge wat voor ons oë gebeur en in ons teenwoordig is, is die sleutel tot kritiek. Sake soos byvoorbeeld mites, bedrog, partyskap ensovoorts, wat voor ons oë plaasvind, is die middel waardeur ons soortgelyke sake in die oorlewerings herken. "Die Beobachtung von Analogie zwischen gleichartigen Vorgängen der Vergangenheit gibt die Möglichkeit, innen Wahrscheinlichkeit zuzuschreiben und das Unbekannte des einen aus dem Bekannten des anderen zu deuten" (Troeltsch 1971: 108).

(c) Korrelasie ("mutual interdependence"): Die verklaring van historiese gebeurtenisse berus op 'n korrelatiewe samehang tussen oorsaak en gevolg (Krentz 1975: 55). Troeltsch (1971: 108-9) noem hierdie derde beginsel “... die Wechselwirkung aller Erscheinungen des geistig-geshichtlichen Lebens, wo keine Veränderung an einem Punkte eintreten kann ohne vorausgegang- 
ene und folgende Anderung an einem anderen, so dass alles Geschenen in einem beständigen korrelativen Zusammenhange stent und notwendig einen Fluss bilden muss, indem Alles und Jedes zusammennängt und jeder Vorgang in Relation zu anderen stent." Wanneer daar dus 'n verandering in die oorsaak is, volg daar ook 'n noodwendige verandering in die gevolg.

\subsection{Probleme met die historiese kritiek}

Dit is veral ten opsigte van die derde prinsipe van korrelasie waarmee daar probleme is. Krentz (1975: 55) stel dit soos volg: "The third principle rules out miracles and salvation history ...", omdat die wonders en die heilsgeskiedenis nie in terme van oorsaak en gevolg verklaar kan word nie.

Dat die histories-kritiese benadering wel voordele het, is nie te betwyfel nie (Krentz 1975: 63-7). Tog het hierdie benaderingwyse wesenlike probleme, omdat dit historisties en positivisties van aard is. Krentz (1975: 30) stel dit pertinent: "This criticism was largely positivist in orientation, imminentist in its explanations, and incapable of appreciating the category of revelation." As die teoloë glo dat die gebeure van die Bybel die resultaat is van die bonatuurlike ingrype van God, is so 'n beskouing 'n hindernis tot die ware historiese verstaan van die Bybel (Harvey 1967: 5). Dit het daartoe gelei dat die Skrifte so te sê gesekulariseer en gerelativeer is, soos Troeltsch (1971: 112) dit eksplisiet stel: "Sie relativiert Alles und Jedes ... in dem Sinne, dass jeder Moment und jedes Gebilde der Geschicte nur im Zusammenhang mit anderen und schliesslich mit dem Ganzen gedacht werden kann ..." (kursifering deur myself). Die geskiedenis wat die Skrif rapporteer, word nie langer meer as korrek aanvaar nie. Daarom kan gestel word dat so vroeg as Johann Semler, wat as die vader van die historiese kritiek beskou word, die historiese kritiek, vanweë die relativering van die Skrifte, nie daartoe in staat was om die Skrifte te laat kommunikeer nie. Vorster (1977: 7) stel dit so: "Johann Salomon Semler (1725-1791) ... het die logiese konsekwensies van hierdie benadering getrek en daarop aangedring dat die Bybel nie slegs grammaties korrek ... maar konsekwent histories beskou moet word as 'n getuienis van die verre verlede wat primêr nie bestem is vir die huidige leser nie" (kursivering deur myself).

Só 'n historistiese geskiedsvisie laat alleen daardie oorsaaklikheid 
("causation") toe wat nie teologies of transendent is nie. Die historiese beskouing wat gebaseer is op die wette van die natuurwetenskap ("laws of natural science") skakel God uit as 'n oorsaaklike faktor en ontken daarom die moontlikheid van wonders (Krentz 1975: 58). Dit is duidelik dat solank 'n ingesteldheid gehandhaaf word, naamlik dat wonders uitgesluit moet word omdat dit nie oorsaaklik verklaar kan word nie (met ander woorde, solank 'n historiese ingesteldheid gehandhaaf word), kan die wonderdade van Jesus nie kommunikeerbaar gemaak word nie.

Dieselfde geld vir 'n positivistiese ingesteldheid dat alle tradisies en geskiedkundige gebeure (ook dié in die Skrif) waar of vals bewys kan en moet word, omdat dit kontroleerbaar en verifieerbaar is uit verskillende buite-Bybelse bronne. Omdat dit egter' $n$ ope vraag bly of die wonders wel geverifieer kan word uit buite-Bybelse bronne (vergelyk afdeling 2.3), het baie positiviste tot die gevolgtrekking gekom dat die wonderdade van Jesus onwaar is. Só 'n positivistiese ingesteldheid belemmer inderdaad ook die kommunikeerbaarheid van die wonderdade van Jesus.

Dit lyk dus of die historiese kritiek die moontlikheid van kommunikasie van die wonders afsny, tensy die historiese kritiek anders hanteer word. Dit het Bultmann inderdaad probeer doen. Hy het aangesluit by die historiese kritiek, maar het dit 'n eie kleur gegee om so die Nuwe Testament te laat kommunikeer (vergelyk afdeling 3.3). Daar is egter ' $n$ ander moontlikheid: byvoorbeeld dié van die siening van Stuhlmacher wat deur Krentz (1975: 68) soos volg verwoord word: "Some theologians therefore ask historians to stay away from the realm of philosophy and leave an open door for the possibility of divine action in history ..." Hiervolgens moet gepoog word om die moontlikheid van goddelike handelinge in die geskiedenis te erken en om só die teks van die Bybel kommunikeerbaar te maak, sonder dat die historiese kritiek daardeur geheel en al van die tafel gevee word (vergelyk afdeling 3.4). Vervolgens word dié twee moontlikhede bespreek.

\subsection{Rudolf Bultmann se onderskeiding tussen "Historie" en "Geschichte" en sy program van "ontmitologisering"}

Die Bybel móét vir Bultmann met die leser spreek wanneer dit gelees word. Die Bybelse teks moet volgens Bultmann nie van 'n afstand "geïnspekteer" word nie, maar moet veel eerder aanvaar word as 
bewerings ("statements") wat bedoel is om die bestaan (eksistensie) van die leser te bepaal (kyk Cahill 1977: 237). Dit is baie duidelik dat Bultmann die kommunikasie van die Bybel hoog aanslaan. Eksegese is vir Bultmann baie belangrik en in hierdie verband (ten opsigte van eksegese) sluit hy sterk by die historiese kritiek aan, soos uit 'n aanhaling van homself (aangehaal deur Cahill 1977: 239) afgelei kan word: "... the task of understanding and translating is subject to very precise disciplines. Exegetical work involves 'the entire history of the words of the text', the lexiographical work, the linguistic research, 'as well as all research into concept and history of religion'." Die objektiewe eksegese van die historisme is egter vir Bultmann onbevredigend omdat alle eksegese volgens hom 'n subjektiewe inset en ' $n$ persoonlike beslissing vereis (Lategan 1982: 62). Verder verset Bultmann hom teen die pretensies van die liberale teoloeë (en ook die positivisme) om geloof op histories-bewysbare gegewens te bou (Van Iersel 1982: 113). Die teks moet op ander wyses as op historistiese of positivistiese wyse kommunikeerbaar gemaak word.

Die Bybel is, behalwe dat dit God se openbaring is, ook produkte van menslike aktiwiteite en derhalwe kan dit op velerlei wyses ondervra word. Dit doen Bultmann ook, veral aan die hand van die "religionsgeschichtliche"-metode. Allerlei vrae na die godsdienshistoriese ag'tergrond van die Bybelboeke, na die historiese Jesus, na die teologie van die Nuwe Testament en dergelike meer word gestel. Dit alles is legitieme en noodsaaklike vrae, maar die meeste van hierdie vrae en ondersoeke gebruik die Bybel as 'n bron van informasie wat die interpreteerder nie persoonlik raak nie. Hierdie geskiedkundige ondersoek moet inderdaad met die grootste moontlike sorg en sonder (of met die minimum) vooronderstelling plaasvind en die resultate kan nooit meer as voorlopig geldig bly nie.

Maar by tekste (en dus ook die Bybel) gaan dit altyd om die verstaan van hierdie tekste as menslike taaluitinge. En verder kan die bestudering en die verstaan, van hierdie uitinge nooit plaasvind sonder dat hulle geinterpreteer word nie. Dit beteken dat 'n suiwer objektiewe benadering wat die interpreteerder weinig raak, ontoereikend is. So werk Bultmann in verband met die objektiewe benadering en die interpretasie daarvan met "... de oppositie tussen wat hij noemt 'historisch' en 'geschichtlich' "(Van Iersel 1982: 114-5). Die grondslag vir die onderskeid tussen "historisch" en "geschichtlich" is geleë in die feit dat die kerugma van die Nuwe Testament 
volgens Bultmann berus op die "dat" van die lewe van Jesus, en nie op die "wat" daarvan nie (Lategan 1982: 62).

Onder Historie/historische verstaan Bultmann die geskiedenis as geslote geheel van samehangende feite, gebeurtenisse en toestande wat met mekaar verband hou in 'n geslote ketting van oorsake en gevolge (Van Iersel 1982: 115). Die historikus staan hier as 't ware objektief buite die gegewens en vra na wat presies gebeur het, byvoorbeeld na die presiese gebeure en handelinge van die historiese Jesus. Hierdie soort geskiedenis (en die beskrywing daarvan) is onderhewig aan die ondersoek deur die geskiedenis-wetenskappe en hulle metodes (Perrin 1979: 33). Dit bied geen basis vir die geloof nie, want daar is niks unieks aan nie omdat "Historie" net verklaar kan word in terme van oorsaak en gevolg. Van hier uit is dit dan ook net moontlik om die "dat" van die Nuwe-Testamentiese gebeure en karakters en nie die "wat" daarvan nie, te bepaal. So kan byvoorbeeld die "dat" van Jesus se doop (Mk 1:9 vv) nie betwyfel word nie, maar hoe dit presies plaasgevind het en wat daardeur bewys moes word, kan nie bepaal word nie. Wat wel "historisch" bepaal kan word is dat die doop 'n legendarese aspek het: "As for the baptism of Jesus, it has a legendary aspect which is as certain as its historical aspect; the actual fact of his being baptized by John the Baptist cannot be doubted, but the account of Jesus's investiture as the Messiah only goes back as far as the period when his life itself was considered messianic ..." (Malet 1969: 64). Dit is vir Bultmann byvoorbeeld "historisch" dat Jesus homself nie as Messias beskou het nie en dat die Hellinistiese Christelike kring waarin die Sinoptiese Evangelies ontstaan het, dit ondenkbaar gevind het dat Jesus gedurende sy leeftyd Homself nie as die Messias beskou het nie. "Consequently the earliest tradition about him was altered in the light of belief in his messiahship ..." (Malet 1969: 67). Bogenoemde is 'n illustrasie daarvan hoe Bultmann die sogenaamde "Historie" behandel het.

Die belangrikheid van geskiedenis jê in die bruikbare lesse wat dit bied vir die hede en toekoms deur te toon hoe die verlede was (Malet 1969: 69). Die historiese proses is 'n proses van gedagtes. "Now the historian cannot perceive ideas as a scientist perceives natural phenomena; he must understand them by reviving them and reliving them ..." (Malet 1969: 78; kursivering deur Malet self). In hierdie verband, naamlik dat geskiedenis as 't ware herleef moet word, onderskei Bultmann "Historie" van Geschichte/geschichtlich. 
Geskiedenis word hiervolgens nie as 'n afgeslote geheel beskou nie. "Geschichte" is geskiedenis in die sin dat 'n gebeurtenis uit die verlede, voortleef in invloed en betekenis vir die hede en toekoms (Perrin 1979: 36; vergelyk ook Van Iersel 1982: 116). Die teks as geskiedenis uit die verlede en as menslike uiting, laat die geskiedsbeskouer en die interpreteerder nie onaangeraak nie. Dit stel hom voor ' $n$ beslissing. Dit raak hom persoonlik in sy geloofslewe. Die teks stel vrae waarop die geskiedsbeskouer moet antwoord: "het stuk tekst dat uit de geschiedenis tot hem komt, blijkt niet te behoren tot een voltooid verleden tijd, maar vraagt nu nog om een keuze" (Van Iersel 1982: 116).

Die geskiedsbeskouer word egter nie sonder meer deur die teks aangespreek nie; daar moet 'n verdere poging aangewend word om die teks te laat kommunikeer. Dit doen Bultmann deur sy sogenaamde "Program van ontmitologisering". Trouens, soos Perrin (1979: 70) beweer, is dit juis die begeerte van 'n prediker wat met sy gemeente wil kommunikeer, wat die basiese impuls agter Bultmann se voorstel is.

Die vroeë Christelike denke is volgens Bultmann volledig gedomineer deur die konsep "mite" (Cahill 1977: 252). Alles in die Nuwe Testament word deur 'n mitiese wêreldbeeld bepaal. Hierdie mitiese wêreldbeeld bestaan daarin dat die wêreld drie verdiepings het, naamlik die aarde in die middel, die hemel daarbo en die onderwêreld daaronder. Oral is daar bonatuurlike magte werksaam. Die geskiedenis gaan nie sy vaste wetmatige gang nie, maar dit is bonatuurlike magte wat beweging en rigting aan die geskiedenis gee. Die heilsgebeure van die Nuwe Testament sluit by hierdie wêreldbeeld aan (Bultmann 1969: 19-20). Daarom is alles in die Nuwe Testament, die wêreldbeeld, voorstellinge van heilsgebeure en gebeurtenisse (ook die wonders) in mitologiese taal gestel. "Daarmee hebben de wonderen van het nieuwe testament als wonderen afgedaan, en wie de historiciteit ervan redden wil met een beroep op zenuwstoringen, hypnotische invloeden, suggestie enzovoorts, bevestigt dit alleen maar" (Bultmann 1969: 24; kursifering deur Bultmann self). Dit is dus duidelik dat ook wonders vir Bultmann mites is (kyk later).

Mitologie hoef nie noodwendig beskou te word as iets wat onwaar of slegs legendaries is nie, maar soos Bultmann (1965: 146), dit self stel: "Mythologie ist der Ausdruck eines Bestimmten Verständnisses der menschlichen Existenz." Hy word deur Schmithals (1968: 257) soos volg aangehaal: "Mythology is a way of representing the other 
worldly in terms of this word, the divine in terms of human life, the 'beyond' in terms of this side.' Myth thus speaks of 'the other world in terms of this world and of the gods in terms derived from human life'." Mite en kultus is noodsaaklike vorme van die eksistensie van godsdienstige gemeenskappe. Maar in sekere periodes van die geskiedenis is dit onmoontlik om 'n kultus of mite van die verlede te laat herleef (Cahill 1977: 251). So word die wêreldbeeld van vandag, asook die menslike eksistensie, nie meer in mitologiese taal uitgedruk nie en kan daar onmoontlik na 'n mitiese wêreldbeeld teruggegaan word. Die Bybelse wêreldbeeld is vir die moderne mens daarom ongeloofwaardig en onaanvaarbaar (Bultmann 1969: 21). Volgens Bultmann (1969: 24) kan 'n mens nie gebruik maak van elektriese lig en radio, 'n mens kan nie in geval van siekte 'n beroep op moderne mediese en kliniese middele doen en tegelyk in die geestes- en wêreldbeeld van die Nuwe Testament glo nie. Omdat die wêreldbeeld van die Nuwe Testament anders en daarom onaanvaarbaar vir die moderne mens is, kan die Nuwe Testament nie kommunikeer, alvorens dit van sy mitiese wêreldbeeld losgemaak is nie. Die teks moet gestroop word van sy mitologiese taal om so by die kern van die Nuwe Testament, naamlik die opstanding van Jesus, uit te kom (Perrin 1979: 73). Om by die wesenlike van die Nuwe Testament uit te kom moet die teks ontmitologiseer word (dit wil sê van sy mitologiese taal gestroop word); eers dan kan die teks kommunikeerbaar in die hede gemaak word en eers dan kan die Nuwe Testament die geskiedsbeskouer voor 'n geloofsbeslissing plaas. Lehmann (1971: 51) stel dit soos volg: "Die Forschung der 'Entmythologisierung' muss erhoben werden, sollen die neutestamentlichen Aussagen für den heutigen Menschen überhaupt noch einen Sinn haben."

Die ontmitologiseringsprogram om 'n teks sodoende kommunikeerbaar te maak, kan aan die hand van Bultmann (1958: 214-28) se behandeling van die wonders in sy artikel "Zur Frage des Wunders", geillustreer word. Hier trek Bultmann die beginsel van ontmitologisering radikaal deur.

Bultmann (1958: 214) begin sy argument ten opsigte van die wonders met die volgende stelling: "... also das Wunder als eine Durchbrechung des gesetzmässige Zusammenhangs des Naturgeschehens; und dieser Gedanke ist uns heute nicht mehr vollziebar." Bultmann beweer dat die wonders niks nuuts of unieks is nie. Hy beweer dat die beginsel van kousaliteit ook ten opsigte van die wonders aangewend kan word. Die wonders word egter op ' $n$ ander kou- 
saliteit as die alledaagse gebeure teruggevoer. Wat hierdie kousaliteit presies is, weet ons nie (Bultmann 1958: 216). Die gedagte van wonders, moet as onuitvoerbaar prysgegee word en hy sluit by Schleiermacher aan wat beweer dat die wonders alleen maar ' $n$ ander uitdrukking van die werklikheid is (Bultmann 1958: 217). Die wonders (of "mirakels", soos Bultmann dit noem) het niks met 'n teenspraak met die wetmatigheid in die natuur te doen nie. Dit is duidelik dat Bultmann, hoewel hy dit nie in soveel woorde sê nie, die wonders wil ontmitologiseer deur kousaliteit daaraan te voeg, deur die uitvoerbaarheid van die "mirakels" te ontken en deur dit te reduseer tot religieuse uitdrukking van die werklikheid.

Wanneer Bultmann die wonders so van hul mitologiese kleed gestroop het, gaan hy verder deur die kern, of saak waaromtrent dit volgens hom in die wonders gaan, te beskryf.

Bultmann beweer dat die betekenis van die wonders daarin lê dat "God doen." Hy stel dit soos volg: "... God doen, ek verstaan ook dat vir my die wêreldgebeure van God se wonder sigbaar sal wees. Ek weet egter dat ek hulle nie sien nie, want die wêreld verskyn aan my as natuur en ek kan myself daarvan nie vrymaak deur die besluit dat dit anders sal wees nie ..." (Bultmann 1958: 220-1; vertaling deur myself).

Tog beweer Bultmann dat daar een wonder bestaan, naamlik die openbaring. Die openbaring van die genade van God lê daarin dat daar vir die goddelose vergewing is. Dit is 'n wonder, want dit, naamlik die vergewing, is in teenstelling met die wêreldgebeure; dit is iets unieks (Bultmann 1958: 221). Om van die sondige verlede en herkoms vry te kom, is alleen moontlik deur vergewing. Dit is 'n daad van God (met ander woorde, "God doen") en dit is 'n wonder (Bultmann 1958: 224).

Die bostaande geld vir die wonders in die algemeen, maar wat van die wonderdade van Jesus? Bultmann (1958: 227) beweer: “. . so gilt doch, dass sie (dit is wonderdade van Jesus - EJV) als Werke eines Menschen der Vergangenheit uns unmittelbar nichts angehen." In die moontlikheid of werklikheid (met ander woorde, die historisiteit van die wonders (oftewel die "dat" daarvan), het Bultmann geen interesse nie. Die wonders word slegs teenwoordig gemaak in die prediking van Jesus. Die wonders moet die geloof versterk en kan deur die geloof alleen "... als das von Gott gesprochen wort der Vergebungs ...", erken word (Bultmann 1958: 228). Jesus wil deur die wonders die openbaring van God konstateer. Bultmann (1958: 
228) sluit af deur te beweer dat die wonders van Jesus ook daarop wys dat die Christelike godsdiens ("Gottesglauben") geen panteïsme en monisme is nie.

\subsubsection{Kritiek op Bultmann}

Bultmann se poging om die teks kommunikeerbaar te maak, het tog enkele probleme. Die grootste beswaar is dat Bultmann die Nuwe Testament (en ook die wonders) verskraal deur dit slegs in terme van die eksistensie-filosofie te verklaar deur die teks te wil ontmitologiseer. Heelwat van die literatuur se skoonheid en eie aard gaan deur ontmitologisering verlore. Van Iersel (1982: 120) merk tereg op: "... dat de tekst van de Bijbel met behulp van andere begrippen nog heelwat meer te zeggen heelft, dat nu verloren gaat wegens de beperktheid van de existentialen waarmee Bultmann werkt" (vergelyk ook Hasel 1978: 100-1).

Bultmann se onderskeiding tussen Historie en Geschichte is myns insiens kunsmatig en onbevredigend. Bultmann wys nie bevredigend daarop hoedanig die "Geschichte" (geskiedenis wat 'n geskiedsbeskouer voor 'n persoonlike keuse bring) wel binne die raamwerk van die "Historie" (objektiewe geskiedenis) plaasvind nie. Die kruis as kerugma kan inderdaad as "Geschichte" beskou word wat die mens persoonlik aanspreek en voor ' $n$ beslissing plaas, maar Bultmann beantwoord myns insiens nie die vraag hoedanig die kruisgebeure binne die "Historie" plaasvind nie of in watter verband die kruisgebeure as "Geschichte" tot die "Historie" staan nie. Verder is "Historie" nie werklik so objektief as wat Bultmann beweer nie. Die historikus kan homself nie geheel en al objektief buite die geskiedenis plaas nie, want sy vooronderstellings bly hom altyd by (vergelyk afdeling 2.3 ).

In Bultmann se behandeling van die wonders lê daar myns insiens 'n probleem. Hy sê dat die wonders nie uniek is nie, dat dit net 'n ander soort kousaliteit het (wat hy myns insiens nie bevredigend kan bepaal nie) en dat dit nie los gesien moet word van die werklikheid nie. Die wonders is myns insiens ook "Geschichte" wat 'n keuse vereis. Daarom kan dit nie sonder meer as "onuitvoerbaar" (Bultmann 1958: 216) of as "... wonderen afgedaan ..." (Bultmann 1969: 24), beskou word nie. Wat van die geloofsaanvaarding as die wonders sonder meer as onuitvoerbaar beskou word?

Daar lê verder 'n bepaalde inkonsekwensie in Bultmann se behan- 
deling van die wonders; eers wys hy alle gebeure wat as buitekousaal beskou kan word van die hand deur te sê dat byvoorbeeld die wonders nie uniek is nie en net op ' $n$ ander manier kousaal as die alledaagse gebeure is; dan gaan hy tog daartoe oor om die één wonder, naamlik die openbaring as buite-kousaal, oftewel as wonder te aanvaar. Dit is myns insiens juis ten opsigte van die kousaliteit wat Bultmann aan die wonders heg, waar die probleem lê. Hy kan nie bevredigend aantoon wat hierdie kousaliteit is nie. Macquarrie (1967: 190) merk tereg die volgende op: “... his interpretation of myth involves not only of talking existentially about human possibilities, but also analogically about God's action. But ... this is the most obscure and unsatisfactory part of his hermeneutics ..." (kursifering deur myself).

Bultmann het inderdaad ' $n$ interessante voorstel aan die hand gedoen om die teks te laat kommunikeer. Hy gaan egter myns insien te ver deur die teks "onaanvaarbaar" te verskraal. Dit lyk myns insiens te eenvoudig om die betekenis van al die wonders te reduseer tot die één betekenis van "God doen", sonder inagneming van wat elke wondervertelling as sodanig mag beteken. Volgens Van Iersel (1982: 125) is Bultmann se tyd verby, omdat daar vandag veel meer interesse in die linguïstiek en literatuurwetenskap as basis vir 'n hermeneutiek is, as 'n filosofiese sisteem.

\subsection{Peter Stuhlmacher se poging om die Bybel kommunikeerbaar te maak}

Stuhlmacher maak in sy hermeneutiek erns met die beginsel van kommunikasie, trouens dit is die hoofdoelstelling van hermeneutiek: "Die Methode der Auslegung Muss dem hermeneutischen Ansatz ebenso entsprechen wie dem biblischen Texten, und sie muss in wissenschaftlichen Gespräch der Gegenwart kommunikabel sein" (Stuhlmacher 1979: 219). Om kommunikasie te bewerkstellig, sluit Stuhlmacher by die historiese kritiek aan: "Wir haben in der Gegenwart keine bessere und leistungsfähigere Auslegungsmethode für Interpretation von sprachlichen Geschichtszeugnissen als die historische Methode" (Stuhlmacher 1979: 207). Die historiese kritiek moet egter nie slegs as 'n wetenskap van historiese analise bedryf word nie, " ... sondern als geschichtliche reflektierte und fundierte Anleitung zur christlichen Lebensverantwortung angesichts des Christuszeugnisses der Schrift" (Stuhlmacher 1979: 207). 
Die historiese kritiek het egter grootliks by analise en beskrywing vasgesteek sodat die groot leemte van die historiese kritiek die uitskakeling van God se werk in die geskiedenis impliseer. Dit het Stuhlmacher aangevoel en volgens hom is die historiese kritiek daarom nie meer in staat om God se werke konkreet in die geskiedenis te verreken nie. Verder is die historiese kritiek nie daartoe in staat om tussen "geschichtswissenschaftlicher" gegewens en wesenlike belydenis van geloof te onderskei nie (Stuhlmacher 1972: 20-1).

Stuhlmacher verwerp egter nie die historiese kritiek geheel en al nie. Hy sluit daarby aan; veral by die drie prinsipes van Troeltsch. Hy voeg egter nog 'n prinsipe daaraan toe, naamlik die sogenaamde prinsipe van "Vernehmens". Hierdie prinsipe is vir hom 'n noodsaaklike toevoeging tot die beginsel van metodiese twyfel. Daar moet by die geskiedenis en die ondersoek daarvan, die bereidheid bykom om die aanspraak van die tradisies, hul "Wirklichkeitsgehaltes" en hul "Wirkungsgeschichte", aan te neem en te verwerk (Stuhlmacher 1971: 149).

Eksegese is volgens Stuhlmacher (1972: 20) " ... nur möglich im Rahmen eine Theologie des dritten Glaubens Artikels." Om geloof te wek is alleen God se voorreg. Die hermeneutiek kan daarom nie die geloof as "verstaansprinsipe" ("Verstehensprinzip") veronderstel nie, "... sondern muss sich damit bescheiden, über ihre Texte in grossmöglicher Offenheit und Klarheit Rechenschaft zu geben" (Stuhlmacher 1979: 219). Daarom moet eksegese bydra om geloof te versterk en so grens Stuhlmacher homself af van 'n onhoudbare skeptisisme wat as gevolg van 'n historiese ingesteldheid ontstaan. Onder die "Vernehmens"-prinsipe verstaan Stuhlmacher dat die interpreteerder in alle eerlikheid die taal aangaande God se handelinge in Jesus Christus, dit is die geloofsuitsprake van die Nuwe Testament, as essensiële waarheid vir die mensdom moet erken (Krentz 1975: 86).

Stuhlmacher wil op die appèl wat die teks tot die mens rig, baie klem lê (De Jonge 1982: 83). Hy is daarvan oortuig dat, by die aanvaarding van die prinsipe van "Vernehmens", die uitlegger die moontlikheid terugkry om die nuwe en analogielose in die geskiedenis te ontdek. Soos hy dit self stel: "Wir gewinnen kraft des zusätzlichen Prinzips des Vernehmens die Möglichkeit zurück, Neues und Analogieloses in der Geschichte zu entdecken, neben den grossen religiösen Einzelnen auch wieder die geschichtliche Bedeutung von sozialen Gemeinschaften zu würdigen und die uns zur Gewohnheit 
gewordenen kausalen Korrelationsschemata durch neue Erkenntnisse aufzuweiten und zu korrigieren" (Stuhlmacher 1979: 220).

Dat die "Vernehmens"-prinsipe as sodanig, los van die ander prinsipes, die moontlikheid open om die unieke en analogielose (dit wil sê ook die wonders) in die geskiedenis te erken, hoef seker nie ontken te word nie. Dit bly egter 'n ope vraag of alleen die openheid tot - en aanvaarding van die unieke en analogielose, tesame met die aanvaarding van die ander prinsipes wat Troeltsch grondliggend aan die historiese kritiek sien, werklik daartoe bydra om die "unieke" en "analogielose" kommunikeerbaar te maak. Kan dit sonder meer aanvaar word dat wanneer die wonders byvoorbeeld as analogieloos en uniek aanvaar word, dit dan noodwendig daaruit volg dat die wondervertellinge vir vandag relevant en verstaanbaar word? Anders gestel: Wat beteken hierdie unieke en analogielose gebeure vir vandag? Stuhlmacher kritiseer die historiese kritiek dat dit geen onderskeid maak tussen "geschichtswissenschaftlicher" en geloofsbelydenis nie. Die vraag is egter of dit werklik die taak van die historiese kritiek as benaderingswyse is om hierdie onderskeid te maak. 'n Laaste beswaar is, of dit wel aanvaar kan word dat die prinsipe van "vernehmens" as toevoeging tot die ander prinsipes van die historiese kritiek, wel kan bydra tot die erkenning van die unieke en analogielose in die geskiedenis, aangesien die unieke juis deur die historiese kritiek en veral deur die prinsipe "korrelasie" vanweë hulle "goddelike kousaliteit" ontken word. Die blote erkenning van die unieke en analogielose as toevoeging tot die ander prinsipes van die historiese kritiek dra dus nie vanselfsprekend daartoe by om die Bybel kommunikeerbaar te maak nie.

\section{5 'n Illustrasie van 'n histories-kritiese studie van 'n "wondervertelling" - die genesing van die Herodiaan se seun (Jh 4:43-54)}

In afdeling 3.2 is daar reeds op gewys dat Bultmann die historiese kritiek in sy eksegetiese arbeid aanwend. Dié benadering word nou geillustreer met behulp van 'n voorbeeld uit sy kommentaar op die Evangelie van Johannes (kyk Bultmann 1971: 204-9).

Johannes 4:43-45 dien as inleiding vir Johannes 4:46-54. Bultmann (1971: 204) beskou Johannes 4:46-54 as 'n redaksionele komposisie van die evangelis. Volgens Bultmann wend die evangelis Johannes $4: 43 \mathrm{v}$ aan om die leser aan 'n ander situasie te herinner. 
Johannes $4: 44$, naamlik dat 'n profeet nie in sy eie land geëer word nie, verwag verdere kommentaar. Johannes $4: 45$ bewys Johannes 4:44 (dat ' $n$ profeet nie in eie land geëer word nie), verkeerd. Tog is die verwelkoming nie eg nie, want die geloof van die mense van Jerusalem (Johannes 2:23) was nie egte geloof nie. Johannes 6:26 vv (dit lyk of Bultmann hier na Johannes 6:26-7 verwys) toon dat so 'n aanspraak, naamlik dat die mense tot geloof gekom het toe hulle die wonderdade gesien het, gou in verwerping omslaan, nadat dit in Johannes 6:14 v'n hoogtepunt bereik het. Johannes 4:44 is dus 'n bewys dat hoofstuk 6 in die oorspronklike vorm op hoofstuk 4 volg. Dit word duideliker as ons sien dat die woorde van Jesus (Jh 4:44) 'n variant is van die tradisie van Markus 6:4, en Johannes 6:41 vv die Johannese variant is van die gebeure in Markus 6:1-6.

Die gedeelte Johannes 4:46-54 toon ooreenkomste met Matteus 8:5-13 en Lukas 7:1-10. Nieteenstaande die groot aantal ooreenkomste, soos byvoorbeeld die genesing van die siek seun, die genesing wat bewerkstellig is deur die woorde van Jesus wat op 'n afstand gespreek is ensovoorts, beweer Bultmann (1971: 205) dat Johannes nie noodwendig afhanklik is van die Sinoptici nie, maar dat Johannes hierdie verhaal uit die sēmeîa-bron geneem het.

Tog is daar ook verskille: 1) Die verhaal vind in die Johannesevangelie nie in Kapernaum plaas nie, maar wel in Kana. Sodoende word die wonder van die genesing oor ' $n$ afstand geïntensiveer. 2) Die vader is in Johannes as ' $n$ heiden beskryf en dit gee nuwe betekenis aan Jesus se aanvanklike weiering om die seun te genees. Johannes 4:48, waarin Jesus die basilikós het glad nie 'n wonder as bewys van Jesus se outoriteit gevra nie. In Johannes 4:49 herhaal die basilikós sy versoek; dit laat Jesus oortuig om op te tree. Deur hierdie twee verskille probeer Bultmann (1971: 205) aantoon dat Johannes ten opsigte van die Sinoptici sekondêr is.

Die besondere karakteristieke van die Johannese vertelling moet aan die evangelis sélf toegeskryf word. Johannes het byvoorbeeld die woorde èlthen ... oinon (Jh 4:46) en ek tēs Ioudaios eis tên Galilaian (Jh $4: 47$ ) as redaksionele toevoegings ingevoeg. (So ook echthès in Jh 4:52.) Daarom, deur hierdie veranderinge, het die evangelis die oorspronklike "punt" van die storie verander om die motief van "pistis en sēmeîa" te illustreer. Dit moes die evangelis gewees het wat die heidense offisier na ' $n$ Joodse (Herodiaanse) hofdienaar verander het (Bultmann 1971: 206).

Johannes $4: 46 a$ is ' $n$ redaksionele verbinding wat die algemene 
situasie beskryf. Johannes $4: 46 \mathrm{~b}$ lei die wondervertelling in. Jh 4:47-50 vorm die korpus van die verhaal. Dit begin by Johannes 4:47 met ' $n$ dringende versoek deur die Herodiaanse hofdienaar. In Johannes 4:48 antwoord Jesus nie eintlik op die vraag nie, want die vader hét immers geloof en daarom het hy na Jesus gegaan. Die enigste verklaring waarom Jesus die versoek eers geweier het, is dat die blote verskyning van Jesus vir die evangelis sou beteken dat mense gekonfronteer word om in Hom te glo as die Openbaarder. Vir die evangelis is dit eerder 'n "misverstand" as "geloof" wanneer daar alleen van Jesus 'n wonderbaarlike verlossing uit fisiese gestremdheid verwag word. Deur hierdie verhaal wil hy die "naïewe geloof" in wonders, soos deur die Sinoptici uitgedruk, herstel en wil hy as motief by die verhaal inwerk dat wonders verwerp word as voorwaarde en bewys vir gesag (Bultmann 1971: 207).

Die voortgang ("progress") van die verhaal word hier gestop, want die antwoord van die vader in Johannes 4:49 neem nie weer die vraag in Johannes 4:48 op nie. 'n Antwoord soos in Matteus 8:8 v word uitgesluit en die dringende versoek word herhaal. Bultmann (1971: 207) interpreteer die versoek soos volg: "I do not ask you to give proof of your authority, I come only in my distress and ask your help for my child." So 'n versoek is 'n teken van ware geloof. Die vader erken sy nood om hulp en dit is genoeg om aan sy versoek te voldoen. (Jh 4:50) epísteusen ho anthrōpos tō lógō hon eîpen autō ho Ièsoûs ... (Jh 4:50b) vorm vir Bultmann (1971: 208) die intensie van die verhaal ("the moral of the story"). Die vader glo sonder om te sien en dit is dié aspek wat uitdrukking is van ware geloof (vergelyk ook Jh 20:29).

Johannes 4:51-53 vorm die konklusie van die wondervertelling. Dit word beheer deur die motief van bevestiging ("attestation"). Die vader bevestig nie die genesing by sy terugkeer nie, maar word van die genesing vertel op pad huis toe. Sodoende is die werksmense bo verdenking as getuies van die wonder, omdat hulle nie die rede vir die genesing voorafgeweet het nie. Hulle bevestig sowel die tyd waarop die wonder plaasgevind het as die oomblik waarop Jesus die besondere genesingswoorde gespreek het. Die gevolg van die wonder was dat die hele huishouding van die regeringsamptenaar gelowig geword het, wat ooreenstem met die konklusies van die ander wonderverhale. Hierdie tradisionele motief is onder invloed van die Christelike sending en die termilogie daarvan herformuleer. Episteusen beteken meer as net dat "hy 'n Christen geword het". Dit ver- 
teenwoordig die stap van die voorafgaande fase van geloof (Jh 4:50) na die eintlike geloof ("faith proper") wat God se ingrypende daad is.

Op hierdie punt moet daar enkele kritiese opmerkings gemaak word ten opsigte van Bultmann se hantering van Johannes 4:43-54. Dit moet in samehang met dit wat in afdeling 3.3 gestel is, gesien word. Die twee beginsels van analogie en korrelasie (vergelyk afdeling 3.1), of saam die "genetiese kousaliteitsbeginsel" genoem, is kenmerkend van die historiese kritiek. Daarom het Bultmann die vergelyking getrek tussen Johannes 4:44 en Johannes 6:26-7, tussen Johannes 6:41 vv en Markus 6:1-6 en Johannes 4:46-54 en Matteus $8: 5-13$. Die wording van die teks en sy verhouding met ander tekste word bepalend vir die betekenis en verstaan daarvan. Die beskrywing van die oorsprong van die teks is tegelykertyd die verklaring daarvan. Die "historische" is vir Bultmann die "oorspronklike" invloed van die skrywer (vandaar die verklaarde redaksionele toevoegings in Jh $4: 46,47$ en 52) en nie die vraag na "wie es eigentlich gewesen ist" van die wondervertellinge self, soos by die historiese eksponente van die histories-kritiese benaderingswyse nie. Om hierdie vraag te ontduik en om uit die "historiese relatiwiteit" van die historisme van die liberale teologie te ontsnap, moet hierdie "historische" "geschichtlich" word. Om hierdie rede soek Bultmann na die intensie van die verhaal (soos by 'n "gelykenis"). Hy vind dit in Johannes 4:50b, naamlik dat die vader geglo het wat Jesus gesê het.

Deur die beginsel van ontmitologisering, hoewel hy dit hier nie uitdruklik uitspel nie, probeer Bultmann die teks kommunikeerbaar maak. Die "naïewe geloof" in wonders, die "mite" dat 'n wonderdader ter wille van gesag wonders doen, soos dit by die Sinoptici voorkom, word as 't ware deur Johannes "ontmitologiseer" en word wonders verwerp as voorwaarde en bewys vir gesag (kyk Bultmann 1971: 207). Die wondervertelling word "eksistensiaal" verstaan. Die Herodiaan ervaar eksistensiële nood en daarom gaan hy na Jesus toe. Dáárin, naamlik dat hy na Jesus gaan in sy nood, lê sy geloof. Dit is ware geloof want hy glo sonder om te sien.

Johannes 4:43-54 kommunikeer dus wel deur middel van die beginsel van ontmitologisering en die "eksistensiale" verstaan wat die ontmitologiseringsbeginsel ten grondslag lê. Die probleem is egter dat Bultmann met 'n filosofiese beginsel ná die teks gaan om dit so te laat spreek. Die eie aard van die teks word so buite rekening 
gelaat of kry ten minste nie voldoende aandag nie (kyk afdeling 3.1.1). Deur meer aandag te gee aan die "vertelkarakter" van wondervertelling, hoef daar myns insiens nie 'n filosofiese beginsel van buite die teks op die teks van toepassing gemaak te word nie. In so 'n geval kan daar meer reg aan die teks geskied sonder om staat te maak op die moontlike herformulering van die invloed van die skrywer op die intensie van die teks. Wanneer die "vertelkarakter" meer tot sy reg kom, hoef daar nie 'n onderskeid gemaak te word tussen "Historie" en "Geschichte" om by die intensie van die teks uit te kom nie.

\section{DIE VERTELLERSPERSPEKTIEF-ANALISE}

\section{Inleiding}

Wanneer die wondervertellinge vanuit die vertellersperspektief-analise benader word, moet daarmee rekening gehou word dat dit as 'n klein vertelling binne die breë geheel van die evangelies beskou moet word (vergelyk afdeling 2.2.3 en ook voetnoot 1). 'n Evangelie is ' $n$ makrovertelling “... en is opgebou uit 'n hele aantal kleiner vertellings met behulp waarvan die skrywer ' $n$ aantal temas rondom die hooffiguur of protagonis van die vertelling ontwikkel het" (Vorster 1980a: 110). Dit is dus van belang dat die resultate van die hedendaagse evangelienavorsing ten opsigte van die vertellersperspektief in aanmerking geneem sal word.

Die evangelies word nie alleen as kerugma of alleen as geskiedenis beskou nie, maar wel as ' $n$ vertelling (Vorster 1982; vergelyk afdeling 2.2.3 vir 'n definisie van 'n vertelling). Verder was die skrywers van die evangelies nie slegs versamelaars of redakteurs van bepaalde Jesus-tradisies nie, maar vertellers. In 'n vertelling wil die skrywer as sender 'n bepaalde boodskap aan die leser as ontvanger oordra (Van Aarde 1982: 34); vergelyk ook afdeling 2.1.2). Brooks (1970: 313) beskou ' $n$ vertelling as ' $n$ soort diskoers wat belangstel in aksie en gebeure in tyd en in beweging; dit is 'n storie of ' $n$ verhaal. Die verteller, wat die skrywer self kan wees, maar nie noodwendig hoef te wees nie, is die literêre term wat gebruik word om die een wat die verhaal vertel, aan te dui. Die verteller "... is ' $n$ rhetorical device the author uses to get the story told and get it told in a certain way" (Rhoads 1982: 420). Die verteller in 'n vertelling maak gebruik van bepaalde karakters (protagonis, antagonis, helpers ensovoorts) wat 
die "plot" konstitueer sodat 'n boodskap aan 'n leser gekommunikeer kan word. Die plot is die plan of struktuur van die gebeure of handelinge in 'n.vertelling wat so gerangskik is dat die verhaal ontvou. In die ontwikkeling van die plot word 'n bepaalde verwagting by die leser gekweek oor hoe die verhaal sal verloop (of afloop) (Vorster 1980a: 126). Die plot doen homself voor in drie sekwensies, naamlik begin, middelstuk en slot. Elkeen wek sy eie bepaalde verwagtings, maar daar kan nie nou op elkeen afsonderlik verder ingegaan word nie. Hier word volstaan met die aanhaling van Petersen (1978a: 47): "'Plot' thus refers to the order of events and their relations as seen in the narrative..."

'n Verteller het 'n vryheid om die karakters en gebeurtenisse in die plot aan te wend net soos hy self wil. Hy kan met ander woorde verberg of vertel wat nodig is ter wille van die ontvouing van sy vertelling en om sy punt te maak. Hy laat die karakters optree en spreek op 'n manier wat hy wil. Vorster (1980a: 118) beweer tereg dat die verteller se posisie nie alleen dié hoef te wees van 'n "objektiewe waarnemer" buite die vertelling nie. Die verteller kan ook sy karakters "intern" beskryf en hy as verteller is vry om in tyd en ruimte in sy vertelling te beweeg en om sy karakters so te gebruik dat hy sy eie perspektief oordra. Die verteller kan ook aan die opeenvolging van gebeure sy eie kronologie gee. As 'n skrywer byvoorbeeld sy eie kronologie aan sy verhaal gee, dan hoef hierdie kronologie nie meer na die kronologie in die werklike wêreld (dit is die opeenvolging van gebeure in 'n bepaalde tydsorde) te verwys nie. (Die probleem met betrekking tot die verhouding tussen "vertelde-" en "werklike wêreld" kom later weer aan die orde; vergelyk afdeling 4.2.)

'n Narratiewe studie wil van die vorm van die betrokke vertelling uitgaan (Petersen 1980: 36). Verder stel Petersen (1978a: 26) tereg: "In literary studies the critics thus became concerned with the things of which a text was 'made', with how they 'worked' to make the text what it was or appeared to be, and with what literary works essentially 'were', that is, ontologically."

Wat die interpretasie van 'n evangelie as vertelling betref, is dit daarom belangrik om te weet hoe 'n verteling "werk" en waarom die verteller vertel soos hy wil. In hierdie verband kan gestel word dat 'n vertelling funksioneer vanuit die perspektief(-we) van die verteller. Met die term "perspektief" word verwys na dit wat literêre kritici "point of view" noem. Beide "plot" en karakterisering het met "narrative point of view" of "vertellersperspektief" te make. Laasge- 
noemde uitdrukking verwys na die wyse waarop ' $\mathrm{n}$ vertelling aangebied word, die perspektief(-we) wat 'n verteller skep waardeur hy die karakters, gebeure en konteks van gebeure vir 'n leser aanbied (Vorster 1980b: 41).

\subsubsection{Die "vertellersperspektief" ("narrative point of view")}

Dit is noodsaaklik om dieper op die konsep van die "vertellersperspektief" in te gaan, aangesien dit wesenlik bydra tot die verstaan van 'n vertelling. Die "vertellersperspektief" word in hierdie studie beskou as die basies "ideologiese" uitgangspunt van die verteller en nie net as tegniese "hoek" van waaruit hy die karakters, tyd en ruimte in 'n vertelling aanbied nie. Literatuur-teoretici soos Brooks, Vandermoere en andere, sowel as die Nuwe-Testamentikus Rhoads gaan daarvan uit dat "point of view" een aspek van die narratiewe studie is: "... so I will here define briefly some basic areas of literary investigation into narrative: plot, conflict, character, setting, narrator, point of view, standard of judgement ..." ensovoorts (Rhoads 1982: 412). In navolging van Uspensky Petersen, Lanser en Van Aarde, word in hierdie studie daarvan uitgegaan dat die "vertellersperspektief" ("narrative point of view") die basiese "ideologiese" perspektief(-we) is van waaruit die verteller sy totale vertelling inrig en vertel.

Die "narrative point of view" (voortaan deurgaans "vertellersperspektief" genoem) manifesteer volgens Boris Uspensky op verskillende "vlakke" in 'n vertelling, naamlik die ideologiese, fraseologiese, topografiese en temporele en psigologiese vlakke.

Wanneer 'n verteller ' $n$ verhaal vertel, is sy eie oordeel altyd teenwoordig. Petersen (1978b:98) haal Weimann soos volg in hierdie verband aan: "... to achieve the necessary selection and evaluation is impossible without a point of view from which to select and evaluate, and this viewpoint ... is indeed the prerequisite of all narrative activity" (kursifering deur myself). Hierdie vertellersperspektief bied aan die verteller vrye keuse ten opsigte van tyd, plek, taalgebruik, karakters, verberging van gebeure, ensovoorts en bied hom die voorreg om selfs gedagtes te "lees". Die verteller rapporteer nie net gebeure nie, hy is vry om karakters en hul handeling en gebeure te evalueer en te kommentarieer. (Dié laaste twee gedagtes word meestal deur die terme "omniscient point of view" en "intrusive narrator" uitgedruk.) Deur hierdie vertellersperspektief probeer die 
verteller die leser manipuleer en oortuig tot 'n bepaalde uitkyk op 'n saak. "Met behulp van die vertellerstandpunt ('point of view') rig 'n skrywer sy 'plot' en karaktertekening in vir die oortuigingswerk wat sy teks moet doen" (Vorster 1980b: 44). In die literatuurwetenskap word onderskei tussen die eerstepersoon-perspektief ("Ek"-vertelling) waar die verteller as 't ware tussen die karakters leef en "binne" die verhaal funksioneer. Verder is daar die derdepersoon-perspektief ("Hy"-vertelling). By laasgenoemde staan die verteller as 't ware "buite" die leefwêreld van die karakters en gebeure (Brooks 1970: 346). Die perspektief van die eerste- of derdepersoon, is die fisiese verhouding van die waarnemer tot die dinge wat hy waarneem (Brooks 1970: 345).

Soos hierby reeds genoem, kan die vertellersperspektief in vier kategorieë of vlakke ingedeel word. Daar sal nou oorgegaan word tot 'n kort bespreking van elke vlak:

\section{(a) Vertellersperspektief op die ideologiese vlak}

Uspensky, soos deur Petersen (1978b: 106) aangehaal, stel dit so: “... from the viewpoint of compositional possibilities, the simplest case ... occurs when ideological evaluation is carried out from a single, dominating point of view. This single viewpoint will subordinate all others in the work ..." Hierdie ideologiese perspektief is die één gesaghebbende idee dwarsdeur 'n teks. Dit gee uitdrukking aan die grondliggende ideologiese perspektief van die vertelling as geheel (Resseguie 1982: 42) wat die verteller in gedagte het wanneer hy die vertelling skryf. Van alle vlakke is dit die minste toeganklik of eerder die minste voor-die-hand-liggend, "... for its analysis relies, to a degree, on intuitive understanding" (Uspensky, aangehaal deur Resseguie 1982: 42).

(b) Vertellersperspektief op die fraseologiese vlak

Dit is die taalkundige manier waarop die vertellersperspektief uitgedruk word. Dit sluit onder andere eerste- of derdepersoon, stemme en toesprake van karakters in (Petersen 1978b: 109). Dit verwys ook na karakterbeelding waardeur norme gebied word om die vertelling aan die hand van sy ideologiese perspektief te lees (Van Aarde 1983b: 66).

(c) Vertellersperspektief op die topografiese en tydsvlak

"These planes represent 'the verbally-established spatial and tem- 
poral relations of the describing subject (the author) to the described event" (Uspensky, aangehaal deur Petersen 1978b: 112). Die verteller beweeg hier vryelik binne selfs die intiemste geselskap en omgewing. Hy neem op ' $n$ afstand as die "onsigbare waarnemer" alles waar wat met die karakters gebeur. Hy is nie aan tyd en ruimte gebonde nie. Te enige tyd en op elke plek beweeg die verteller as ' $t$ ware "met" die karakters. (Kyk Petersen 1978b: 112-5 en Van Aarde 1983b: 72-9).

\section{(d) Vertellersperspektief op die psigologiese vlak}

Hierdie vlak beskryf die gedagtes, gevoelens en emosies van die karakters. Die verteller kan hierdie gedagtes objektief beskryf, maar self ook subjektief beoordeel en weergee (Petersen 1978b: 116). Die verteller ken die gedagtes van die karakters. Hy vestig die leser se aandag op die gevoelens en innerlike motiewe van die karakters waarvolgens hulle optree (Resseguie 1982: 42). Baiekeer is hierdie motiewe van die hoofkarakter ook die perspektief van die verteller (kyk Van Aarde 1983b: 70-2).

In teorie is hierdie onderskeiding tussen die vlakke geregverdig. In praktyk is hierdie onderskeid nie so maklik aanwysbaar nie en moet dit gestel word dat die onderskeid eerder in die verhouding van die vlakke tot mekaar lê. Die vertellersperspektief is 'n relasie eerder as 'n konkrete entiteit. Hoewel die ideologiese vlak nie so duidelik sigbaar is nie, is dit tog die basis-idee van die verteller. Dit is die "... deep compositional structure as opposed to the surface compositional structures" (Uspensky, aangehaal deur Resseguie 1982: 42; kursifering deur myself). Wat is dan die verhouding tussen "deep compositional structure" en "surface compositional structures"? Die ideologiese vlak in ' $n$ vertelling is grondliggend aan die ander vlakke (dit is gesien vanuit die perspektief van die verteller). "Dit kom met ander woorde daarop neer dat die verteller se ideologiese perspektief manifesteer op die fraseologiese, psigologiese, en tyd-en topografiese vlakke ..." (Van Aarde 1983b: 62; kursifering deur Van Aarde self). Vanuit die analise van die verteltegniek waarvolgens die "oppervlaktestrukture" georganiseer is, word die ideologiese perspektief geïdentifiseer. Lanser (1981: 18) stel dit so: “... we can also entertain the possibility of more complex links between ideology and technique through the structuring of point of view. It is possible that the very choice of a narrative technique can reveal and embody ideology." Later stel sy dit so: ". . point of view can function at once as ideology 
and technique" (Lanser 1981: 63). Dit ly geen twyfel dat daar 'n wesenlike verband bestaan tussen die ideologiese perspektief en die ander vlakke nie. Van Aarde (1983b: 62) skets dié verhouding deur'n grafiese voorstelling wat (met enkele wysigings) soos volg daar uitsien:

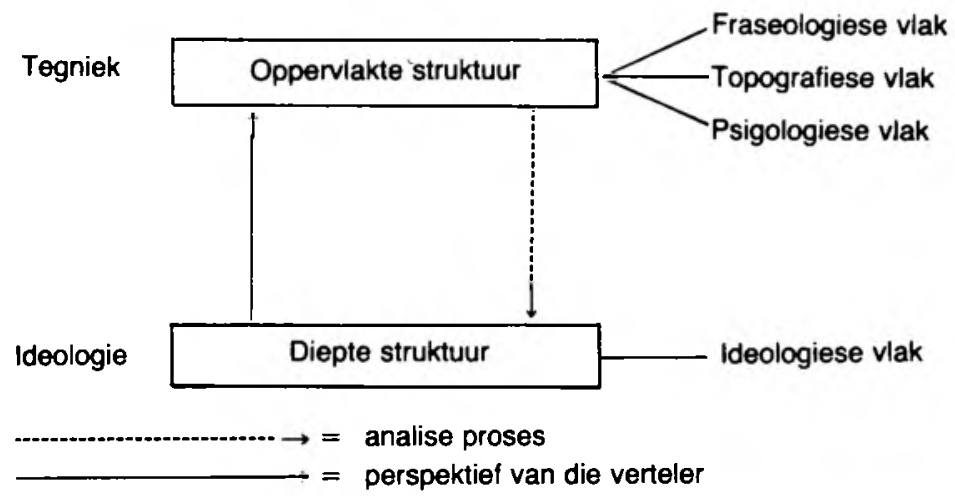

Die verhouding is egter veel breër as wat hierbo uitgedruk is. "Point of view controls 'the reader's impression of everything', that 'in the relationship between the teller and tale, and ... between the teller and the audience, lies the essence of narrative act'" (Scholes, aangehaal deur Lanser 1981: 12). In 'n vertelling is daar 'n komplekse netwerk van interrelasies tussen outeur, verteller, karakters en gehoor (Lanser 1981: 13). Dit is dus duidelik dat die ideologiese perspektief veel wyer is as net 'n "angle of vision" waarvolgens 'n verteller "fisies" na die gebeure kyk. Dit is die hele ideologiese standpunt en ingesteldheid of veronderstelling waarvolgens die verteller alles in sy vertelling (karakters, helpers, plot, protagonis, ensovoorts) aanwend om sy standpunt aan die leser oor te dra.

\subsection{Die onderskeid tussen "vertelde wêreld" en "werklike wêreld"}

Du Toit (1980: 13) beweer dat 'n nagaan van die evangelies toon dat Jesus se geskiedenis nie so reglynig met die evangeliese berigte verbind kan word nie. Du Toit (1980: 8) stel dit tereg dat die evangelies nie mites was nie, ook nie naakte historie nie, maar vertolkte geskiedenis. Du Toit (kyk ook Bultmann se hantering van Jh 4:43-54 hierbo) gaan egter nie verder nie en laat die feit dat die evangelies 
"vertellinge" is, buite rekening. Dit is die feit dat die evangelies vertellinge is, wat lig werp op die onderskeid tussen "vertelde-" en "werklike wêreld".

Uspensky word deur Petersen (1978b: 78) soos volg aangehaal: "In a work of art ... there is presented to us a special world with its own space and time, its own ideological system, and its own standards of behaviour." Dieselfde geld ook vir die evangelies (en ook die wondervertellinge) as vertellings (vergelyk afdeling 2.2 .3 ). In verteltekste word 'n "vertelde wêreld" geskep, wat as sodanig geïnterpreteer moet word (Vorster 1980b: 27). Vorster is verder tereg van mening dat die wêreld wat in 'n vertelling altyd 'n "vertelde wêreld" ("narrated world") sal bly, selfs al gebruik die verteller gebeure wat werklik plaasgevind het (Vorster 1982: 8).

Wanneer beweer word dat die verteller 'n "vertelde wêreld" skep, kan 'n letterlike interpretasie, waar die "werklike wêreld" regstreeks uit die "vertelde wêreld" afgelei word, nie moontlik wees nie. Petersen (1978a: 39) wys daarop dat daar tog 'n soort verhouding bestaan tussen die "werklike wêreld" as objek en die narratiewe teks waarin 'n "vertelde wêreld" uitgedruk word. Hierdie twee "wêrelde" is nie regstreeks dieselfde nie, maar die verhouding lê daarin dat die teks (en dus ook die "vertelde wêreld"), die "werklike wêreld" herskep om ' $n$ boodskap aangaande ' $n$ bepaalde saak mee te deel. Die verteller vertel ' $n$ verhaal soos hy dit sien (met ander woorde, soos hy die werklike gebeure sien). Hy sien die werklike gebeure en skep dan $\mathbf{n}$ eie "wêreld". Dit wat hy sien, hoef nie los van die "werklike wêreld" te staan nie, maar sodra die verteller dit vertel of skryf, dan ontkoppel hy die verhaal aan die "werklike wêreld" en word dit 'n indirekte binding tussen "vertelde" en "werklike wêreld" (Petersen 1978b: 98). Die verhouding en onderskeid tussen hierdie twee "wêrelde" lê daarin dat die "werklike wêreld" nie "betekeniskonstituerend" in die vertelling is nie, maar wel "betekenisreliëfgewend". Dit beteken dat werklike gebeure nie regstreeks van belang is vir die verstaan van die teks nie, maar dat dit wel die agtergrond of "dekor" bied waarteen die vertelling afspeel.

Lanser (1981: 57) koppel hierdie onderskeid regstreeks aan die vertellersperspektief; die verteller skep 'n beeld van die "wêreld" soos gesien vanuit sy besondere gesigspunt. Ten opsigte van die evangelies as vertellings, moet daarop gewys word dat die band wat die evangeliste as vertellers met die "werklike wêreld" gehad het, die tradisiestroom van die vroeë kerk was. Die materiaal wat hulle 
gebruik het, was dus nie uit die duim gesuig nie, maar word deur elke individuele redaktor-verteller (dit wil sê, die evangeliste) só aangewend dat elk sy eie aksent kry. Die tradisies word tot 'n sinvolle geheel saamgestel sodat 'n verhaal vertel word (Vorster 1980b: 40). Die tradisie-materiaal word so die agtergrond waarteen die vertellers hulle vertellings vertel.

\subsection{Die vertellersperspektief-analise se hantering van "historisiteit" en "kommunikasie"}

Hierdie deel staan in 'n noue verband met die voorafgaande deel oor die onderskeid tussen "vertelde" en "werklike wêreld" en moet dus in dié lig gesien word.

Rhoads (1982: 413) beweer tereg dat die "narratiewe kritiek" met die teks as "wêreld-in-sigself" werk: "Narrative criticism brackets these historical questions and looks at the closed universe of the story-world." Wanneer daar met die teks as vertelling gewerk word, word daar sinchronies daarmee omgegaan, met ander woorde, net die "vertelde wêreld" word geanaliseer. Die teks funksioneer los van die historiese skrywer en funksioneer as geslote wêreld met sy eie kenmerke (Van Aarde 1983b: 58). Dit kan nie as blote "fiksie" beskou word nie, want dit sluit by die oorgelewerde tradisies aan en herinterpreteer dit tot 'n eie teologiese idee of verhaal. Hierdie verhaal word opgebou uit die eie perspektief van die verteller (Van Aarde 1982: 34). Dit is duidelik dat die historiese vrae en "historisiteit" genuanseerd ' $n$ rol in die vertellersperspektief-analise of 'n "narratiewe eksegese" inneem (kyk later in hoofstuk 5).

Dit is belangrik om op die rol wat die vertellersperspektief-analise tot "kommunikasie" kan bydra, te let. Petersen (1980: 38) beweer dat, alhoewel 'n vertaling van die teks wel nodig is, ons onsself in die posisie van die geïmpliseerde lesers, dit is hulle tot wie die verteller spreek, kan plaas omdat die verteller spreek tot wie ook al bereid is om te hoor: "We can listen to what he says and respond with the ideas and image he evokes ... a literary reading of a narrative text begins at a moment we allow ourselves to be addressed by its textually immanent narrator" (kursifering deur myself). Dit is vir Petersen tereg moontlik vir 'n vertelling om te kommunikeer, solank die leser dit toelaat dat die teks hom aanspreek. Met ander woorde, die teks kommunikeer wanneer die leser deel word van die vertelling. Die leser raak al hoe meer vertroud met die perspektief van die verteller, 
hy word daardeur aangespreek en keer op dié manier, namate hy oortuig word deur die perspektief van die verteller, na sy eie wêreld terug met 'n verrykte eie perspektief.

"Kommunikasie" van die vertelling gaan verlore wanneer "historiese" vrae, soos dié na "wie es eigentlich gewesen ist", die invloed van die historiese skrywer of dié na die wording van die teks, aan die teks gestel word. Die vraag wat aan 'n vertelteks ter wille van kommunikasie (en daarom ook aan 'n wondervertelling) gestel moet word, is: "In hoe ' $n$ mate is ek bereid om myself deur die vertellersperspektief te laat aanspreek en/of te laat oortuig?" By die wondervertellings soos dit deur die evangeliste vertel is, word daar vertel van wat Jesus gesê en wat hy gedoen het.

Dit vertel die verteller vanuit 'n bepaalde perspektief met die doel om die leser van iets te oortuig. Die leser moet deur die vertelling tot dieselfde perspektief(-we) van die verteller oortuig word. Die wonders kan alleen kommunikeerbaar gemaak word in soverre die leser homself deur die perspektief van die verteller laat bevra of laat oortuig en nie deur te vra na die historiese korrektheid of moontlikheid van Jesus se wonderdade of ander "historiese" vrae nie.

\section{4 'n Illustrasie van 'n narratiewe studie van 'n "wondervertelling" - die genesing van die verlamde man (Mk 2:1-12)}

Daar het op die gebied van die "narratiewe eksegese" van NuweTestamentiese tekste tot op hede (1983) nog nie veel publikasies die lig gesien nie. Norman Petersen is van die eerste Nuwe-Testamentici wat diể nuwe benadering in die eksegese begin toepas het. Vir die doeleindes van hierdie studie, word van die resultate van sy ondersoeke gebruik gemaak. Petersen (1978b: 99-102) se narratiewe uitleg van die wondervertelling oor die genesing van die verlamde man in Markus 2:1-12, word derhalwe vervolgens kortliks weergegee.

"Toe Jesus na 'n paar dae weer in Kapernaum kom, het dit bekend geword dat $\mathrm{Hy}$ by die huis is" (Mk 2:1)4. Met hierdie woorde begin Markus die agtergrond van die vertelling te beskryf. Op hierdie stadium is die leser nog nie werklik betrokke by die vertelde karakters, handelinge en omgewing ("setting") nie, maar word tog stadig "ingetrek" in die verhaal.

"Baie mense het daar saamgedrom, sodat daar selfs by die deur nie meer plek was nie. Hy was besig om met hulle oor sy boodskap 
te praat. Daar kom toe mense wat 'n verlamde man na Hom toe bring. Vier van hulle het hom gedra. Toe hulle hom weens die gedrang nie by Jesus kon kry nie, breek hulle die dak reg bokant Hom oop, en nadat hulle 'n opening in die dak gemaak het, laat hulle die draagbaar waarop die verlamde man gelê het, daardeur afsak. Toe Jesus hulle geloof sien, sê $\mathrm{Hy}$ vir die verlamde: 'Vriend, jou sondes word vergewe!"” (Mk 2:2-5). Die verteller verskuif die vertelde gebeure tot binne in die huis waar die verteller èn leser alles wat die karakters sien, hoor, doen en sê, waarneem soos 'n onsigbare waarnemer vanuit 'n interne gesigshoek.

"Maar sommige van die skrifgeleerdes het daar gesit en hulle afgevra: 'Waarom sê hy so? Hy praat mos godslasterlik! Wie kan sondes vergewe behalwe God alleen?' Jesus het dadelik geweet dat hulle by hulleself so redeneer. Hy sê toe vir hulle: 'Wat redeneer julle by julleself hieroor? Wat is makliker? Om vir die verlamde te sê: 'Jou sondes word vergewe', of om te sê: 'Staan op, vat jou draagbaar en loop? Maar Ek gaan nou vir julle die bewys lewer dat die Seun van die mens volmag het om op die aarde sondes te vergewe.' Hy sê toe vir die verlamde man: 'Ek sê vir jou: Staan op, vat jou draagbaar en gaan huis toe'" (Mk 2:6-11). Die verteller bied sy vertelling vanuit die so genoemde "omniscient point of view" aan. As "alomteenwoordige" verteller het hy die leser nie net toegang tot binne-in die huis verleen nie; as "alwetende" verteller lig hy die leser in van die "onsigbare", soos byvoorbeeld die gedagtes van die karakters.

Markus 2:8 wys op 'n ander punt: Een van die karakters, naamlik Jesus, besit dieselfde "vermoë" om gedagtes te lees as die verteller self. Drie dinge word in hierdie verband waargeneem:

(a) Jesus sien in die optrede van hulle wat die verlamde bring, geloof raak. Hy waardeer dit positief en tree gunstig op teenoor die verlamde.

(b) Die skrifgeleerdes beskou Jesus as godslasteraar. Jesus kan hulle gedagtes lees en $\mathrm{Hy}$ waardeer hulle negatief as teenreaksie op hulle innerlike bevraagtekening.

(c) "Hy het opgestaan, dadelik sy draagbaar gevat en voor die oë van almal uitgestap. Hieroor was hulle almal verbaas en het hulle God geprys en gesê: 'So iets het ons nog nooit gesien nie!'" (Mk 2:12). Die leser verneem dat almal, ook die skrifgeleerdes, verbaas was ten opsigte van die daad van Jesus met betrekking tot die verlamde man. Die vertelling eindig hier, sonder goedkeu- 
ring of afkeuring (ten minste nie eksplisiet nie) van die skrifgeleerdes se mening. Tog is die feit dat die verteller die skrifgeleerdes teenoor die hoofakteur stel, genoegsame aanduiding van die verteller se negatiewe beoordeling van die skrifgeleerdes.

Petersen (1978b: 100) verduidelik verder die verskillende "perspektiewe" ("points of view") wat in hierdie perikoop aanwesig is. Hierdie "perspektiewe" bewerkstellig 'n struktuur van verhoudings tussen:

(a) die verteller en sy leser,

(b) die verteller en die karakters,

(c) die leser en die karakters en

(d) die karakters self. Die "perspektiewe" van die karakters illustreer die "perspektief" van die verteller. Met behulp van hierdie "perspektiewe" lei die verteller die leser in die "vertelde wêreld" van die teks in.

Wat die verhouding tussen die verteller en leser betref, formuleer Petersen (1978b: 101) dit soos volg: "The narrator reaches out of his narrative to lead his reader on an imaginative journey into the past, plucking him out of his time and place, as it were, and setting him down in another time and place." Hierdie stelling kan veral deur Markus 2:1 geillustreer word. Beide verteller en leser word "onsigbare" waarnemers van die handelinge van 'n groep mense in die vertelling oor die verlede. Hierdie "verlede" is egter die "weerspieëlde" ("imaginative") verlede tyd van die "vertelde wêreld" in die vertelling: "... a moment in the narrative's own world, which must not be confused with the real-world past of the narrator or reader" (Petersen 1978b: 101). Dit is myns insien op hierdie punt dat die leser ingetrek word in die verlede wêreld en dat die teks kommunikeer. So kry die leser onwillekeurig deel aan die vertelling en spreek die "perspektiewe" van die verteller (en ook dié van die karakters hom aan). Deurdat die leser in die "vertelde wêreld" "ingetrek" is, vind hy uit dat die verteller die gedagtes van die karakters ook kan lees en dat die verteller hierdie "vermoë" met die hoofkarakter deel. Die leser kry derhalwe insae in die gedagtegang en motiewe ("perspektiewe") van die karakters en kry ook so deel aan die vertelling se "vertelde wêreld". Dit dra daartoe by dat die teks kan kommunikeer, want die verteller lei die leser om die karakters saam met hom te beoordeel. 
Wat die verhouding tussen die verteller en die hoofkarakter betref, is die verteller vertroud met die gedagtes en gevoelens van die hoofkarakter (Mk 2:8). Petersen (1978b: 102) formuleer die verteller se insae in die "psigologiese perspektief" van die hoofkarakter soos volg: "... the narrator is aligned - if not identified - with the central actor." Die leser kan hieruit aflei dat die "perspektief" van die verteller net so betroubaar is as die "perspektief" van die hoofakteur Jesus en vice versa. Hierdie "perspektief" wil die verteller ook aan die leser oordra, deurdat hy dit as norm aanwend, waarvolgens hy wil hê dat die leser die vertelling moet lees. (Wat hierdie "perspektief" presies is, sal later op teruggekom word.) Op hierdie manier word die leser gelei om homself met die hoofkarakter te vereenselwig. Myns insiens is dit juis op hierdie punt waar die vertelling kommunikeer. Die verteller lig die leser in wat net hy en Jesus geweet het. Petersen (1978b: 102) sluit dan soos volg af: "From the beginning to end, the reader is totally dependent on the narrator's characterizing and evaluation of the actors, their actions, and their motivations."

Aangesien Petersen sover nog een van die weinige eksegete is wat die "narratiewe eksegese" toepas, is dit te verstane dat daar baie leemtes in sy behandeling kan wees. Een daarvan is dat hy nêrens eksplisiet stel wát die "perspektief" van die verteller presies is nie. Daar kan nie in diepte op die leemtes ingegaan word nie, maar dit is nodig om op hierdie punt enkele eie gedagtes as uitbreiding tot die illustrasie toe te voeg. Daar is reeds op gewys dat die "perspektief" van die verteller dieselfde is as dié van Jesus. Die verteller trek die leser stelselmatig in die vertelling in tot by die punt waar die leser ook as "onsigbare" waarnemer die gedagtes van die hoofkarakter kan lees. Die verteller vertel dat Jesus die geloof van diegene wat die verlamde ingebring het, gesien het en dat dit daartoe gelei het dat Jesus sondes vergewe. Die verteller stel daarteenooor die skrifgeleerdes (dit is die antagoniste), wat beweer dat net God sondes kan vergewe. In reaksie teen hierdie "perspektief" beredeneer Jesus hulle gedagtes en evalueer $\mathrm{Hy}$ dit negatief, aangesien $\mathrm{Hy}$ (as Seun van die mens) volmag het om sondes te vergewe. Dan genees Jesus die verlamde man en almal is verbaas daaroor.

Wat opval is dat hierdie vertelling baie uitgebreid oor die gebeure rondom die wonderdaad vertel. Die vertelling lê klem op die "perspektiewe" van die vertelde karakters (geloof, antagonisme en bereidheid tot vergiffenis en optrede), maar rapporteer baie min oor 
die wonderdaad self. Uit Markus 2:5 kan nog nie afgelei word dat Jesus reeds die wonder laat plaasvind het nie; dit is net Markus 2:11-12a wat dit eksplisiet stel dat die wonder in opdrag van Jesus plaasgevind het. In samehang met die feit dat Markus 2:1-12 deel is van 'n vertelteks waarin die verteller se "perspektief" die riglyn uitmaak (vergelyk afdeling 4.1) waarvolgens die Markusevangelie as geheel gelees moet word, kan beweer word dat die verteller in hierdie perikoop nie soseer die wonderdaad as sodanig wou beklemtoon nie, maar wel die "perspektief" (of "motief") van Jesus wat aanleiding tot die daad gegee het. Die verteller is vry om as "onsigbare", "alomteenwoordige" waarnemer juis die "perspektief(-we)" weer te gee wat hý wil. Dit is dat Jesus op grond van geloof sondes vergewe en dat hy die volmag daartoe het. Jesus tree op na aanleiding van geloof wat hy waarneem; trouens sy optrede is bewys van sy volmag om sondes te vergewe en dit is weliswaar ook 'n wonder op sigself. Die wonder word inderdaad deur die verteller vertel, maar die klem val op die vergewingsgesindheid van Jesus. So gesien is die antagonisme van die skrifgeleerdes 'n verdere bevestiging of versterking van Jesus se optrede.

Wat die verteller aan die leser wil oordra, is dus nie soseer die wonderdaad as historiese bonatuurlike gebeurtenis nie (dit word weliswaar nie ontken nie), maar wel die vergewensgesindheid van Jesus op grond van geloof. Dít is die "perspektief" van die verteller wat gekommunikeer word, naamlik die boodskap van vergewing van sondes (vergelyk ook Mk 1:4 en 1:15).

Skematies kan die "perspektief" van die verteller soos volg weergegee word:

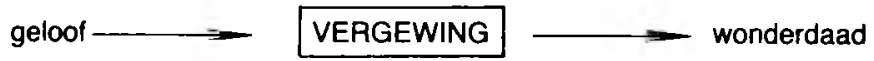

\section{EVALUASIE}

Wanneer die vraag gestel word na watter benaderingswyse of eksegetiese metode gevolg moet word om 'n wondervertelling te laat kommunikeer, kan beweer word dat die historiese kritiek, sowel die historistiese as die positivistiese komponente daarvan, nie geskik is as uitlegmetode vir die wondervertellinge nie. Die rede hiervoor is dat die beginsels van "analogie" en "korrelasie" die teks grootliks relativeer en die unieke en analogielose in die Bybel uitskakel. Sodoende kan die teks, vir solank as 'n historistiese en positivistiese 
ingesteldheid gehandhaaf word, nie kommunikeer nie, omdat die vraag na historisiteit in terme van "wie es eigentlich gewesen ist", onbeantwoord bly en die teks so per implikasie niks meer vir vandag te sê het nie (vergelyk afdeling 3.2). Bultmann probeer die historisiteitsprobleem anders hanteer deur sy onderskeid tussen "Historie" en "Geschichte" en sy program van "ontmitologisering". Sodoende slaag hy wel daar in om die Bybel vir vandag verstaanbaar en daarom ook kommunikeerbaar te maak, maar verskraal tog die teks daardeur onregverdiglik (vergelyk afdeling 3.3.1). 'n Verdere probleem, soos die illustrasie van Johannes 4:43-54 (vergelyk afdeling 3.5) blyk, is dat Bultmann op die "genetiese kousaliteitsbeginsel" terugval om die teks te verklaar.

Stuhlmacher probeer ook aansluiting vind by die historiese kritiek deur die aanvaarding van sy beginsel van "Vernehmens", waarvolgens die unieke en analogielose in die Bybel erken word. Hierdie beginsel staan egter in ' $n$ innerlike kontradiksie met die beginsel van "korrelasie" van Troeltsch. Verder is dit ook nie vanselfsprekend dat die blóte aanvaarding van die unieke en analogielose in die Bybel tot verstaan en tot kommunikasie móét lei nie (vergelyk afdeling 3.4).

Die teks moet dus aan die hand van 'n ander (myns insiens 'n beter) metode van uitleg kommunikeerbaar gemaak word sonder dat die erkenning of verwerping van die unieke en analogielose noodwendig ' $n$ probleem is nie en sonder dat die teks onregverdiglig verskraal hoef te word. Die "narratiewe eksegese" (vergelyk hoofstuk 4) kan hieraan voldoen. Die historiese kritiek word nie hiermee geheel en al verwerp nie. Dit bly nog ' $n$ rol speel, nie soseer as uitgangspunt vir interpretasie nie, maar wel om agtergrondgegewens te bied in soverre dit sigself in die teks manifesteer. So kan ' $n$ ondersoek na die lewens- en wêreldbeskouing van die Fariseërs, wat deur die historiese kritiek vasgestel kan word, byvoorbeeld moontlik daartoe bydra om die antagonistiese houding van hierdie karakters teenoor Jesus in Markus 2:1-12 beter te begryp. Dit bied sodoende addisionele inligting wat noodsaaklik kan wees vir die verstaan van die teks. Dit is veral die sogenaamde "Redaktionsgeschichte" wat 'n bydrae kan lewer tot verstaan, omdat dit die moontlikheid bied om 'n teks as geheel, met ander woorde as redaksionele werk in sy geheel, uit te lê (vergelyk Petersen 1978a: 17-8). Dit is veral op die fraseologiese vlak van die vertellersperspektief waar die historiese kritiek ' $n$ bydrae kan lewer (vergelyk afdeling 4.1.1(b)). 
Die rede waarom die "narratiewe eksegese" beter kan kommunikeer, lê in die feit dat historisiteit anders hanteer word. Historisiteit funksioneer op 'n ander vlak in die "narratiewe eksegese" as in die historiese kritiek. In die "narratiewe eksegese" funksioneer historisiteit nie op die vlak van "wie es eigentlich gewesen ist" of op die vlak van die wordingsgeskiedenis van die teks nie (vergelyk afdeling 2.3). Vanweë die eie aard van die vertelmateriaal (vergelyk afdeling 4.2 en 4.3) speel historiese gegewens nie 'n betekenis-konstituerende rol nie, maar 'n betekenisreliëfgewende rol. Of dit Jesus self was wat die wonderdade bewerkstellig het en hoe dit presies plaasgevind het, is nie in die "narratiewe eksegese", in teenstelling met die historiese kritiek, betekeniskonstituerend nie. Met ander woorde, die verstaan en kommunikasie van die wondervertelling hang nie daarvan af of dit Jesus self was wat die wonderdaad bewerkstellig het nie. Dit word weliswaar nie ontken nie, aangesien dit berus op ' $n$ bepaalde na-pase tradisie wat in die vroeë kerk as "histories" korrek aanvaar is, maar dit is kragtens die aard van vertelmateriaal nie bepalend vir die verstaan van die wondervertelling nie. Om hierdie rede bied die "narratiewe eksegese" 'n moontlikheid vir die teks om te kommunikeer omdat historisiteit van die staanspoor in hierdie verband anders as in die historiese kritiek hanteer word. Historisiteit word in die "narratiewe eksegese" as betekenisreliëfgewend hanteer. Die historiese gegewens wat sigself in die teks manifesteer, dien as agtergrondgegewens by die teks. Dit bied, soos reeds vroeër gestel, addisionele inligting tot beter verstaan van die karakters, plot, ruimte en tyd, ensovoorts van die vertelling.

Bultmann, in sy hantering van Johannes $4: 43-54$, het, soos reeds aangedui, aangesluit by die historiese kritiek en moes daarby 'n onderskeid maak tussen "Historie" en "Geschichte", asook 'n "ontmitologiseringsprogram" ontwerp wat op 'n bepaalde filosofiese ingesteldheid berus, om die teks kommunikeerbaar te maak. Hy het wel daarin geslaag om die vertelling te laat kommunikeer, maar hy moes dit aan die hand van 'n filosofiese sisteem van buite die teks doen sonder voldoende inagneming van die eie aard van die vertelteks (vergelyk afdeling 3.5). Daarteenoor het Petersen in sy hantering van Markus 2:1-12 rekening gehou met die wondervertelling as vertelteks. Op die manier is gelet op die wyse waarop die perikoop "gemaak" is (die "poëtiek" van 'n teks) en kon die perikoop kommu- 
nikeerbaar gemaak word kragtens sy eie aard, sonder filosofiese sisteem van buite die teks af (vergelyk afdeling 4.5).

Op hierdie punt het dit nodig geword om enkele kritiese opmerkings te maak ten opsigte van die "narratiewe eksegese" en die rol wat historisiteit en kommunikasie daarin speel. Deist (1980: 49) beweer dat die begrip "werklikheid" in die literêre kritiek soos Vorster dit aanwend, te eng is. Die werklikheid van die teks is volgens Deist veel breër en sluit die sosio-politieke en die godsdienstige konteks, outeur, gehoor, ensovoorts in. Deist wil die teks in sy historiese konteks plaas wat op sigself nie verkeerd is nie, maar die beswaar wat Deist hier opper, is myns insiens nie heeltemal regverdig nie. Die rede hiervoor is dat die onderskeid tussen vertelde en werklike wêreld nie hoef te impliseer dat die teks los van sy historiese konteks staan nie. "Die beklemtoning van die feit dat 'n vertelling ... referensieel na 'n 'binnetekstuele wêreld' verwys, hoef natuurlik nie 'n achroniese interpretasie te impliseer nie" (Van Aarde 1982: 33).

Die "narratiewe eksegese" "systap" nie noodwendig die historisiteit van die wonders geheel en al nie. Dit bied 'n beter oplossing as die historiese kritiek en red so die vertelling uit die "kloue" van die liberalisme en skeptisisme wat beweer dat die evangelies (en ook die wondervertellinge) onwaar is, omdat dit nie volgens die beginsels van die historisme en positivisme verklaar kan word nie en derhalwe nie in staat is om nog iets vir vandag te sê nie. Soos reeds hierbo gestel, hanteer die "narratiewe eksegese" die historisiteitsvraag anders as die historiese kritiek. Van Aarde (1983b) stel dit soos volg: "Die bepaling van die historiese, godsdienstige, sosiologiese en ekonomiese konteks waarteen die evangelies sinchronies gelees moet word, is nie deel van dié metode nie ... dit is 'n studie op sy eie." Dit kom daarop neer dat die historiese vraag (in terme van "wie es eigentlich gewesen ist" en die wording van die teks) nie deel is van die ondersoek na die vertelde wêreld nie. Die historiese konteks is 'n probleem van histografie ("histography") en nie 'n literêre probleem in die eerste plek nie (kyk Vorster 1983). Verder merk Vorster (1980b: 45) tereg op dat wanneer die historiese vraag aan 'n vertelteks gestel word, die teks oorinterpreteer word. Die "narratiewe eksegese" lê veel meer klem op die kommunikasie-aspek in ooreenstemming met die kenmerke wat intrinsiek deel is van 'n vertelteks. Die vraag na historisiteit belemmer hierdie wesenlike vraag na kommunikasie. Hierdie vraag na kommunikasie is naam- 
lik: "Hoe spreek die wondervertelling my aan?", "Hoe oortuig die teks my tot die siening van die verteller?" of "hoe kan ek die perspektief van die verteller relevant maak in my lewe?"

Ter afsluiting moet gestel word dat die "narratiewe eksegese" geensins 'n absolute "die" metode van interpretasie (kyk afdeling 2.1.1) vir die wondervertelling wil wees nie. Ook word die historiese kritiek geensins geheel en al verwerp nie. Wat hier betoog word, is dat die "narratiewe eksegese", as 'n betreklik nuwe metode van interpretasie, ' $n$ beter moontlikheid bied om die wondervertelling na sy aard as vertelteks te laat kommunikeer.

\section{Verwysings}

1. Daar moet 'n onderskeid gemaak word tussen die begrippe "tekssoort" (vergelyk afdeling 2.1.2) en "tekstipe". Die begrip "tekssoort" word as breëre begrip aangewend om die verskillende soorte tekste in die Nuwe Testament te onderskei ter wille van kommunikasie. Die begrip "tekstipe" is 'n fynere onderskeiding wat binne die begrip "tekssoort" gebruik word. So kry 'n mens onder "tekssoort" saaktekste die sogenaamde Sendbriewe as "tekstipe", terwyl dit nog fyner onderverdeel kan word in byvoorbeeld geloofsformules, belydenisse ensovoorts.

2. "Openbaringsgebeure" moet hier in die wydste sin gesien word.

3. Ook Bultmann sluit hierby aan (vergelyk afdeling 3.3).

4. Daar word deurgaans aangehaal uit: Die Nuwe Testament en die Psalms. 1979-vertaling. Met woordelys en teksverwysings. Kaapstad: Bybelgenootskap van Suid-Afrika.

\section{Literatuurverwysings}

ABRAHAMS, W] 1982. Divine revelation and the limits of historical criticism. Oxford: Osford.

ANDEREGG, J 1983. Fiktion und Kommunikation. Göttingen: Vanderhoeck.

BETZ, O 1977. Wesen und Wirklichkeit der Wunder Jesu. Frankfurt: Lang.

BROOKS, C 1970. Modern rhetoric. Third Edition. New York: Harcourt.

BULTMANN, R 1958. Zur Frage des Wunder, in Glauben und Verstehen. I. Tübingen: Mohr, 214-28.

BULTMANN, R 1965. Jesus Christus und die Mythologie, in Glauben und Verstehen. IV. Tübingen: Mohr, 141-89.

BULTMANN, R 1969. Geloof zonder mythe? Roermond: Ramen.

BULTMANN, R 1971. The gospel of John: A commentary. (Translated by GR BearsleyMurray). Oxford: Blackwell.

CAHILL, PJ 1977. The theological significance of Rudolf Bultmann. TS 38, 231-74.

DEIST, FE 1980. Tekssoort evangelie: ' $n$ weerwoord ThEv 13, 49-51.

DE JONGE, M 1982. De historisch-kritische methode, in Klijn, AFJ (red) 1982. Inleiding tot de studie van het Nieuwe Testament. Kampen: Kok, 71-85. 
DU TOIT, AB 1980. Algemene inleiding tot die evangelies, in Du Toit, AB (red) 1980. Handleiding by die Nuwe Testament. IV. Die Sinoptiese Evangelies en Handelinge: inleiding en teologie. Pretoria: NG Kerkboekhandel, 1-30.

FRÖR, K 1964. Biblische Hermeneutik; zur Schriftauslegung in Predigt und Unterricht. München: Kaiser.

FULLER, RH 1963. Interpreting the miracles. London: SCM.

GEREFORMEERDE KERKEN NEDERLAND, 1981. God met ons. Over de aard van het schriftgezag. Utrecht: Tijl-Libertas. (Special Kerkinformatie 113).

GLASSWELL, ME 1965. The use of miracles in the Markan Gospel, in Moule, CFD (ed) 1965. Miracles. London: Mowbrays, 149-62.

HARVEY, VAN A 1967. The historian and the believer: The morality of historical knowledge and christian belief. London: SCM.

HASEL, G 1978. New Testament theology: Basic issues in the current debate. Grand Rapids: Eerdmans.

KALLAS, J 1961. The significance of the sinoptic miracles. London: SCM.

KRENTZ, E 1965. The historical-critical method. Philadelphia: Fortress.

LANSER, SS 1981. The narrative act. Point of view in prose fiction. Princeton: University Press.

LATEGAN, BC 1982. Inleiding tot de uitlegging van het Nieuwe Testament, in Klijn, AFJ (red) 1982. Inleiding tot de studie van het Nieuwe Testament. Kampen: Kok, 47-70.

LEHMANN, K 1971. Der Hermeneutische Horizon der historisch-kritischen Exegese, in Schreiner, J (hrsg) 1971. Einfürung in die Methode der Biblischen Exegese. Würzburg: Echter, 40-80.

MACQUARRIE, J 1967. God-talk. London: SCM.

MALET, A 1969. The thought of Rudolf Bultmann. (Translated by R Stracham). Shannon: Irish Uniersity Press.

NORTH, CR 1962. History, in I D B. 2. Nashville: Abindon, 607-12.

PERRIN, N 1979. The promise of Bultmann. Philadelphia: Fortress.

PESCH, R 1970. Jesu Ureigene Taten. Freiburg: Herder.

PETERSEN, NR 1978a. Literary criticism for New Testament critics. Philadelphia: Fortress.

PETERSEN, NR 1978b. "Point of view" in Mark's narrative. Semeia 12, 97-119.

PETERSEN, NE 1980. Literary critics in biblical studies, in Spencer, RA (ed) 1980. Orientation by disorientation. Studies in Literary criticism and biblical literary criticism. Pittsburgh: Pickwick, 25-50.

PETZKE, G 1976. Die historische Frage nach den Wundertaten Jesu. Dargestellt am Beispiel des Exorzismus Mark. ix., 14-29 par. NTS 22 (2), 180-204.

RHOADS, D 1982. Narrative criticism and the gospel of Mark. JAAR 50, 411-34.

RESSEGUIE, JL 1982. Point of view in the central section of Luke (9:51-19:44). JETS 25/1, 41-7.

SCHMITHALS, W 1968. An introduction to the theology of Rudolf Bultmann (Translated by J Bouden). London: SCM.

STANTON, GN 1979. Presupposition in New Testament criticism, in Marshall, IH (ed) 1979. New Testament interpretation. Exeter: Paternoster, 60-71.

STUHLMACHER, P 1971. Neues Testament und Hermeuneutik - Versuch einer Bestandsaufrahme. ZThK 68, 121-61.

STUHLMACHER, P 1972. Thesen zur Methodologie gegenwärtiger Exegese. ZNW 63, $18-26$.

STUHLMACHER, P 1972. Vom Verstehen des Neues Testaments. Eine Hermeneutik. Göttingen: Vandenhoeck.

SWINBURNE, R 1970. The conept of miracles. London: Macmillan.

TAYLOR, WM 1975. The miracles of our saviour. First Edition. Grand Rapids: Kregel.

TERRY, MS 1976. Biblical hermeneutics. Grand Rapids: Zondervan. 
THISELTON, AC 1979. The new hermeneutic, in Marshall, IH (ed) 1979. New Testament interpretation. Exeter: Paternoster, 308-33.

TROELTSCH, E 1971. Über Historische und Dogmatische Methode in der Theologie, in Sauter, G (hrsg) 1971. Theologie als Wissenschaft. München: Kaiser, 73-104.

VAN AARDE, AG 1982. God met ons. Dié teologiese perspektief van die Matteusevangelie. Pretoria: Universiteit van Pretoria (ongepubliseerde DD proefskrif).

VAN AARDE, AG [1983a]. Eksegese van vertelmateriaal. Pretoria: Universiteit van Pretoria (ongepubliseerde seminaarreferaat).

VAN AARDE, AG 1983b. Die vertellersperspektief-analise. ' $n$ Literatuur-eoretiese benadering in die eksegese van die evangelies, in Van Aarde, AG (red) 1983. Interpretasiemodelle in evangelienavorsing. Pretoria: Universiteit van Pretoria, 58-83.

VAN DER LOOS, H 1968. The miracles of Jesus. First Edition. Leiden: Brill.

VANDERMOERE, H 1976. The study of the novel. A Structural approach. Leuven: Acco.

VAN IERSEL, BMF 1982. Die existentiale interpretatie, in Klijn, AFJ (red) 1982. Inleiding tot de studie van het Nieuwe Testament. Kampen: Kok, 112-26.

VOGT, J 1976. Aspekte erzählender Proza. 2. Auflage. Opladen: Westdeutscher.

VORSTER, WS 1977. ' $n$ Ou boek in 'n nuwe wêreld-gedagtes rondom die interpretasie van die Nuwe Testament. Pretoria: Universiteit van Suid-Afrika.

VORSTER, WS 1980a. Die evangelie volgens Markus: inleiding en teologie, in Du Toit, AB (red) 1980. Handleiding by die Nuwe Testament. IV. Die Sinoptiese Evangelies en Handelinge: inleiding en teologie. Pretoria: NG Kerkboekhandel, 109-55.

VORSTER, WS 1980b. Die tekssoort evangelie en verwysing. ThEv 13, 27-48.

VORSTER, WS 1983. Kerugma/history and the gospel genre. NTS 29, 87-93.

WOODS, CF 1965. The evidential value of the biblical miracles, in Moule, CFD (ed) 1965. Miracles. London: Mowbrays, 19-32. 